\title{
Heritage Language Loss in the Chinese Community in Argentina
}

\author{
Calvin Ho \\ Fall 2010 \\ Senior Honors Thesis \\ Department of Linguistics \\ Swarthmore College
}




\section{Abstract}

A rapid linguistic shift is happening in the Chinese community in Argentina, one of the newest immigrant groups in the country. Second- and third-generation Chinese-Argentines are quickly abandoning their home language variety (e.g. Taiwanese or Fujianese) for Spanish. At the same time, their parents are sending them to weekend language schools to acquire Standard Mandarin, a variety distinct from the language of the home.

Through an ethnographic study of a weekend language school in Buenos Aires Chinatown, I seek to explore the phenomenon of language loss in the Chinese-Argentine community. In order to provide sufficient background to explain the linguistic and sociological phenomena observed, this paper will begin by providing a description of the Chinese community in Argentina, outlining theories of language loss in minority communities, and reviewing historical language shifts in China and Argentina. After laying out this framework, I will then describe the ethnographic project and analyze the observations I gathered in the field.

I find that the Chinese community in Argentina is generally following the Fishman (1965) model of language shift, in which the Argentine-born second-generation is dominant in Spanish and chooses to raise children in that language, meaning that subsequent generations are monolingual in Spanish. However, weekend language schools complicate this shift by teaching Standard Mandarin to the youth of the community. Because second- and thirdgeneration children are still acquiring Standard Mandarin in these schools, Chinese language and culture are being maintained at some level; however, it is still unclear how stable this maintenance is. What is clear is that because there is little to no reinforcement outside of the home, non-standard varieties of Chinese will not survive past the second generation. I hope that this paper will spur further research on the Chinese-Argentine community, on which there is very little social science literature. 


\section{Foreword}

This thesis was written on the basis of my ethnographic study of the Chinese community of Buenos Aires, Argentina in the latter half of 2009. During my stay in Argentina, I engaged in participant observation at a weekend school teaching Chinese language to Chinese-Argentine youth. As I was placed in a first-grade class, interviewing the students would have been very difficult, so instead I observed them in their interactions with each other and with their teachers. Additionally, I conducted semi-structured interviews with three teachers, two of whom taught the first grade class that I observed, and one who teaches Chinese as a foreign language to Argentines with no Chinese background.

Aside from my fieldwork in Buenos Aires, in writing this thesis I also drew on other

resources and experiences. I spent the 6 months immediately after I left Argentina studying Chinese language in Taiwan, where I made casual observations about language use in society and had conversations with several friends and teachers about the state of bilingualism in that country. Additionally, my own experiences as a member of the Chinese diaspora in the United States and a former student at a similar Chinese language school inform my observations and analyses.

In order to protect the privacy of my informants, all names of persons and institutions in this thesis are fictitious. ${ }^{1}$

\section{DEFINITION OF TERMS}

Terms relating to China and Chinese language

History and politics have made the terms "China," "Chinese culture," and "Chinese 
language" very confusing, especially to those who may be less familiar with the region. During the Chinese Civil War, fought between the Communists and the Nationalists in the mid-20 ${ }^{\text {th }}$ century, the Communists took over the mainland region and the Nationalists were pushed out to the island of Taiwan. Thus, there came to be two Chinas: a People's Republic of China on the mainland (referred to as Mainland China in this thesis) and a Republic of China on Taiwan (referred to simply as Taiwan). The terms China and greater China refer to these two regions as a collective entity; in the same vein, Chinese culture refers to the culture that these two regions have historically shared.

The language(s) of greater China present their own terminological problems. Some claim that there is a singular "Chinese language" with many "dialects;" others (including the majority of linguists outside of greater China) believe that some of these "dialects" are languages in their own right. In order to sidestep this debate, I will use the term varieties of Chinese. Varieties of Chinese that share a close genetic relationship and are generally mutually intelligible may be categorized into dialect groups.

The term Standard Mandarin refers to the official language variety of both Mainland China and Taiwan. It is important to distinguish Standard Mandarin from the dialect group to which it belongs, known simply as Mandarin. Calling it Standard Mandarin also avoids the complicated political nuances of its many Chinese names, particularly Guoyu ("national language," used in Taiwan) and Putonghuas (“common speech," used in Mainland China). I will refer to varieties of Chinese other than Standard Mandarin as local vernaculars.

Terms relating to immigration and immigrant communities

First generation immigrants are those who immigrate to another country as adults; the second generation consists of the children of the first generation, and the third generation 
consists of the children of the second generation. The 1.5 generation refers to those who immigrated to another country before adolescence. Argentine-born Chinese will be used as a collective term to refer to the second, third, and subsequent generations.

Borrowing a term from Kenner (2004: 152), I will refer to weekend or after-school institutions that teach Chinese as a heritage language as "complementary schools" or "Chinese complementary schools" because they complement the mainstream school system with subjects that are not normally taught.

\section{TRANSCRIPTIONS, TRANSLATIONS, AND ENDNOTES}

Chinese terms in this thesis will be transcribed according to the Hanyu Pinyin ${ }^{4}$ system used to transcribe Standard Mandarin into the Roman alphabet, and will be set off from the English text using italics. For clarification, the first time that a Chinese term is used, the term will be written out in traditional Chinese characters in an endnote. Personal and place names are spelled according to the transcription most commonly seen in English texts (e.g. Taipei; Kuomintang). Translations of the titles of foreign language sources cited have been have been provided alongside the original title in the Works Cited section. Direct quotations from Spanish or Chinese sources will be translated in the text, with the original quotation provided in an endnote.

1 I would like to thank Dr. Gabriel Noel of the Facultad Latinoamericana de Ciencias Sociales - Argentina for helping me tackle the methodological problems that I encountered in the field, and Dr. K. David Harrison of Swarthmore College for his help with the theoretical portion of this thesis. I would also like to thank Alexandra Israel for her helpful commentary on the first two drafts of this thesis, María Paula Luciani for her assistance with Spanish-English translations, and the wonderful people of Academia Hsin-Yi for welcoming me to their school and letting me do my observations and interviews there.

2 國語 


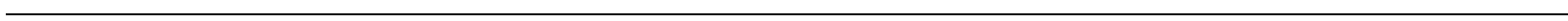

3 普通話

4 漢語拼音 


\section{Introduction}

I am Chinese. I am Overseas Chinese. I love China. I also love this country [that I live in]. ${ }^{1}$

My Chinese complementary school classmates and I read this passage aloud several times out of our textbook. I was perhaps 10 years old at the time, and even at that young age, that passage frustrated me. Am I Chinese? That did not make any sense to me. I lived in the United States, spoke English as my primary language, and ate spaghetti and hamburgers, just like every other American kid out there. Sure, my parents were born abroad, and we speak Cantonese and eat Chinese and Vietnamese food at home, but didn't that just make me a more specific type of American? A Chinese-American, or an Asian-American, perhaps? Why did this textbook insist on telling me who I was and how I should identify?

A more important question: why am I in school on a Saturday morning, mindlessly repeating a passage that directly challenges my sense of self, in a language I barely understand?

The passage above is one of the few things that I remember learning in Chinese complementary school, which I attended every Saturday of the school year from second grade to sixth or seventh grade. Despite consistently being at the top of the class, I learned very little Chinese in the years that I spent at the school. It did not matter that I could barely speak any Standard Mandarin; as long as I could regurgitate passages with reasonably good pronunciation and write my characters neatly, I would get good grades and be able to reassure my parents that the thousands of dollars that they spent every year on complementary school tuition was not 
going to waste.

The teachers at the school were all very nice, but did not succeed in teaching me much Chinese. To begin with, I speak Cantonese at home, and they were Taiwanese immigrants teaching Standard Mandarin to a class consisting mostly of students who spoke Standard Mandarin at home. This is akin to putting a Spanish speaker in a "French for native speakers" class. Their insistence on rote memorization, and the fact that we were using textbooks designed for students much younger than us, did not help matters. I learned to write my name, and to recognize a few characters, but not much more.

As time went on, my classmates and I grew more and more disenchanted with our education (and the fact that we sat in school on weekends). We would act out our frustration in class by disregarding the authority of our teachers and administrators. We socialized loudly in class (in English), got up out of our seats without permission, and doodled in our books-things that "model minority"2 Asian-American students would never dare do in the mainstream classroom.

I also started venting my frustration to my parents. I was not learning anything, I said. I did not like the fact that I was sitting in a classroom on Saturday mornings, copying Chinese characters from the whiteboard until my hands cramped. I implored my parents to reconsider the utility of the Chinese language in a world in which English was king (I did not discover my naïveté about the issue until a decade too late). Only towards the end of middle school did they finally give in to my demands. If I really did not want to go to Chinese school, what could they do?

My parents were initially so adamant that I learn the Chinese language because, in their minds, I am irrefutably Chinese. They grew up in Vietnam, a non-Chinese speaking country, but identify only as Chinese and speak the language perfectly. In fact, they preferred speaking 
Chinese to speaking Vietnamese, which they picked up on the street. Why was it, then, that I was abandoning my Chinese for English? Why was it that, whenever I tried to speak Chinese, every other word that came out was English, and that every day my Chinese seemed to be getting worse and worse? My parents were worried that, if this trend were to continue, we would never be able to understand each other. The generational and cultural gaps were quite enough; adding on a language barrier would make communication all but impossible.

When I went to study abroad in Argentina in August of 2009, I hoped to plunge into the Chinese community in Buenos Aires and discover its similarities to and differences from Chinese communities in the United States. In particular, I wanted to know if second-generation Chinese-Argentines confronted the same problems that I and my peers struggled with. Are they Argentine? Are they Chinese? Are they somewhere in between? Should they speak Spanish or Chinese? (Is that an either-or question? Can they speak both?) Do their parents force them to go to Chinese complementary school on the weekends, too?

I discovered that Argentine-born Chinese are indeed very similar to American-born Chinese in these respects. On the opposite side of the world, in a Spanish-speaking Latin American country, they were also struggling to find their place in a society that marked them as outsiders because of their different physical features. They were also abandoning their parents' language for the dominant language. They were also sent by their parents to complementary schools to learn Chinese.

However, I also discovered many differences between Chinese-Argentines and ChineseAmericans, most of which are due to the fact that the United States and Argentina are entirely different contexts to grow up in. While the United States is an affluent, multicultural superpower, Argentina is a largely homogeneous developing nation trying to regain its wealth 
and influence after a long period of economic and political decline.

The two countries also have very different orientations towards languages and language learning. While many Americans do not see a pressing need to learn a foreign language, and in fact may refuse to learn a foreign language because of pride in the United States' continued cultural, political, and economic dominance, Argentines feel that learning foreign languages, English and Chinese in particular, is instrumental in getting ahead. This difference in attitudes towards language is critical to an understanding of how heritage language loss works in the two countries.

\section{HERITAGE LANGUAGE LOSS AND THE FISHMAN MODEL OF LANGUAGE SHIFT}

Before we begin, we must define heritage language loss, the central linguistic concept in this thesis. Heritage language loss is the process by which a person raised in a home in which a minority language is spoken (a heritage speaker) shifts from speaking this language (the heritage language) as his or her dominant language to speaking the language of the majority as the dominant language (University of California, Los Angeles 2001). Due to heritage language loss, heritage speakers generally have a weaker ability in the heritage language than in the majority language. This language loss occurs because of a variety of factors, including the perceived low prestige of the heritage language and the lack of reinforcement and development of heritage language skills in the school system.

The term "heritage language loss" and the terms from which it derives have become the focus of some controversy, as some posit that the word heritage (along with similar words like ancestral) alludes to the past and implies that the language is no longer in current use (Van Deusen-Scholl 2003: 217). However, in the absence of another suitable term to describe the particular sociolinguistic circumstances in which a heritage speaker is raised, this thesis will 
follow the literature's prevailing usage of heritage speaker and heritage language.

Heritage language loss is most commonly discussed in the context of immigrant communities. The generation most affected by this phenomenon tends to be the second generation, those who are born to immigrant parents33. Studies have shown that heritage languages in the United States generally do not survive beyond the second generation; indeed, even second generation speakers tend not to be able to use the language in all situations and with the full complexity of structure, vocabulary, and idiomatic usage expected of native speakers. In 1965, Fishman demonstrated that, with European immigrants to the United States, the first generation uses the heritage language fluently and in all domains, while the second generation only speaks it with the first generation at home and in limited outside contexts. As English is now their dominant language, members of the second generation tend to speak English to their children; thus, subsequent generations grow up monolingual in English (Fishman 1965: 146).

\section{WHY STUDY HERITAGE LANGUAGE LOSS?}

While much has been said about the value to the field of linguistics of studying languages on the verge of extinction (see Harrison's [2007] When Languages Die), the vast majority of immigrants to receptor countries like the United States and Argentina speak major languages that have been thoroughly studied. Furthermore, even if these languages cease to be spoken in the countries of settlement, they are generally still widely spoken in the immigrants' homelands, and in the case of languages of empires or diasporas like Spanish and Chinese, also in other communities around the globe.

Although the ways in which heritage speakers' use of the language differs from other native speakers' use of the language may be of interest to more theoretical branches of 
linguistics, heritage language loss is far more interesting and far more significant when approached from the twin lenses of sociolinguistics and sociology of language. The complex language attitudes that lead to language shift are of interest to sociolinguistics, while the ways in which power relations between dominant and minoritized social groups manifest themselves through the proxy of language politics are of interest to sociologists of language. Study of a given population's heritage language loss can also shed light on how communities maintain bilingualism and how receptor countries incorporate immigrant minorities into the mainstream.

While heritage language loss has been relatively well researched in the United States and other affluent, English-speaking countries that are home to large numbers of immigrants, there have been few studies of this topic outside of the developed world. Does heritage language loss occur in immigrant communities outside of English-speaking developed regions? If so, how does the way in which this phenomenon arises in the developing world add to our understanding of language shift in immigrant communities?

\section{THE FISHMAN MODEL, REVISITED}

In the 45 years that have passed since Fishman's paper, researchers have generalized this model (now called "the Fishman model of language shift") to describe the trend of heritage language loss in other immigrant groups in the United States (López 1996: 146). Portes and Schauffler's (1996) study of bilingualism in Miami showed that the Fishman model was applicable to Latin American immigrant communities, as well. They discovered that children of immigrants "[demonstrated] an unambiguous preference" for English and that this "rapid transition toward monolingualism" affected all children of immigrants in the study regardless of their parents' education level, a factor used as a proxy for socioeconomic class (Portes and Schauffler 1996: 28). The authors concluded that even dense immigrant enclaves like Miami 
have little hope of maintaining bilingualism past the first generation without the help of policies that support and foster heritage language maintenance and development.

Fishman himself has also refined the model over the years, and has shifted his orientation slightly, from describing the phenomenon of heritage language loss to theorizing ways in which groups can reverse language shift. One central idea from his 1991 book, Reversing Language Shift: Theoretical and Empirical Foundations of Assistance to Threatened Languages, is that intergenerational mother tongue continuity (that is, heritage language maintenance) is highly dependent on the maintenance of boundaries between cultures and within cultures. Between cultures, such boundaries may mean "separation of populations, the control of boundary crossings, the regulation of imports, [and] the definition of desirable and undesirable cross-boundary relations" (Fishman 1991: 356). Oftentimes, language minorities are unable to maintain these boundaries because of their dependence on the dominant group for their advancement and well being. "Interactive dependency and relatively open access to educational, economic and political rewards for the most fully transethnified and translinguified individuals" of the language minority means that "ethnocultural minorities not only learn the 'outside' language but displacively use it with one another, on the 'inside', for advantages which also obtain even within the weakened and transculturating minority community itself" (Fishman 1991: 357, emphasis in the original). Thus, as a result of assimilation and integration, the language of the dominant culture becomes the language of highest prestige and begins to be used in all situations, even in intragroup communications within the minority population.

What might the advantages of speaking the majority language within the community be? The advantages obtained within the community may be closely linked to those obtained without. For example, speaking the majority language may link the individual to the dominant culture: because I speak the dominant language, I am part of the dominant culture. This may happen in 
societies like the US and Argentina where immigrants and other language minorities face significant pressure to assimilate into the mainstream. For some sectors of immigrant minorities, speaking the majority language may also link members of the community to each other. This may happen among the second generation and some members of the 1.5 generation, who face the most pressure to assimilate and struggle to differentiate themselves from less assimilated first and 1.5 generation members of the community: because we speak the dominant language, we are our own subset of our community, and are culturally closer to the dominant majority than to the stigmatized minority.

\section{IS THERE HERITAGE LANGUAGE LOSS IN THE CHINESE-ARGENTINE COMMUNITY?}

The purpose of this study is to investigate whether there is heritage language loss in the Chinese community in Argentina, and whether Fishman's model of language shift can adequately account for what is happening there. An additional dimension of analysis in this thesis is which variety of Chinese is being lost or maintained in the Chinese-Argentine community. Parents who are native speakers of one variety may choose to pass on another variety (perhaps of higher prestige) to their children. For example, native speakers of Taiwanese may choose to speak only in Standard Mandarin to their children for a number of reasons. This complicates the question of heritage language loss because while one variety is lost, another may be maintained.

The United States and Argentina share many characteristics that make comparisons of assimilation and acculturation in both countries very appropriate. As Cortés Conde (1993: 46) notes, "the historical development of Argentina up until the Second World War was very similar to that of the United States.” European immigration fueled the economic expansion of both countries in the $19^{\text {th }}$ century. Descendants of these European immigrants form the majority of 
both populations, and both countries characterize themselves as nations of immigrants. Furthermore, in recent decades, both countries have been struggling to cope with the arrival of immigrants from Latin America and Asia. Immigration from Mexico has consistently been a hot topic in American political discourse, and, while less prone to controversy, immigration from countries like China, Vietnam, and the Philippines has also increased dramatically. In Argentina, the primary immigration "problem" is the perceived increase in immigration from nearby South American countries, particularly Bolivia, Paraguay, and Peru (Grimson n.d.: 1)4.

Another similarity between the United States and Argentina is that immigrants of Chinese origin in both countries have set up schools teaching Chinese as a heritage language, as a way to combat the perceived threat of cultural and linguistic loss in subsequent generations. Furthermore, both countries are responding to the rise of China as a political and economic power in different ways, due to differences in their standing in the global arena. How do Chinese-as-a-heritage-language schools in the two countries compare? How do national perceptions of foreign languages in general, and the Chinese language in particular, affect the rate of heritage language loss?

In analyzing heritage language loss among Chinese-Argentines, it is important to put it in historical perspective within Argentina. Thus, comparisons will be made to previous waves of immigrants to Argentina, with special focus on the British and Korean communities.

\section{LANGUAGE ATtitudes}

Scholars have not decided on a clear-cut definition of the term "language attitude." Hidalgo, in her study of language attitudes in Ciudad Juárez, Mexico, defined the term as referring to value judgments about one language variety as opposed to another (Hidalgo 1986: 
196). Crystal's definition in A Dictionary of Language, Second Edition, though even more vague than Hidalgo's, provides some insight into why language attitudes are important to research on heritage language loss. Crystal defines "language attitudes" thusly:

The feelings people have about their own language or the language(s) of others. These may be positive or negative: someone may particularly value a foreign language (e.g. because of its literary history) or think that a language is especially difficult to learn (e.g. because the script is off-putting).... Knowing about attitudes is an important aspect of evaluating the likely success of a language teaching programme or piece of language planning. (Crystal 2001: 186, emphasis added).

Positive language attitudes are crucial to language acquisition and language maintenance. Those who feel that the target language is important to them and their sense of self, and is also useful to them in some way, are more likely to learn a new language or maintain one that they already speak. Gardner and Lambert, pioneers in the study of language attitudes, introduced the concepts of integrative and instrumental orientations towards language learning. Language students who exhibit an integrative orientation towards learning a second language are those who have a "genuine interest" in the culture of the speakers of the target language and seek to build personal connections with these persons (Gardner and Lambert 1972: 14). On the other hand, students who exhibit an instrumental orientation towards language learning may not have such an interest in the culture surrounding the target language and are "interested mainly in using the cultural group and their language as an instrument of personal satisfaction” (Gardner and Lambert 1972: 15). While learners with integrative orientations value cultural understanding and inclusion more highly, learners with instrumental 
orientations value the language as a cultural or economic asset for themselves.

In their study of the motivation of Israeli teenagers for learning English, Cooper and Fishman (1977: 272) built upon Gardner and Lambert's ideas, finding that "those who see a knowledge of English as contributing to important personal goals [e.g. being cultured and having different kinds of experiences] are likely to learn it best and to use it most." Cooper and Fishman's findings suggest that learners do not have one of Gardner and Lambert's orientations or the other. Rather, second-language learners have complex motivations that may combine elements of both orientations, and those whose motivations are related to goals that they view as more important are more likely to gain higher levels of proficiency.

From the theoretical findings in these two studies, we might predict that students in complementary schools who have positive attitudes towards the Chinese language are the students who will be most successful at maintaining it. Positive language attitudes may be associated with feeling strongly connected to Chinese culture and seeing proficiency in Chinese as a cultural or economic asset. Additionally, they may see their connection to Chinese culture and proficiency in Chinese language as serving important personal goals (according to their own definition).

An individual's attitudes towards a language, whether positive or negative, are informed by society's perception of that language and the people who speak it. From my field observations and interviews, along with my own experience as a person of Chinese descent living in Argentina for a short time, I have perceived that Argentine society has conflicting perceptions of China, Chinese people, and Chinese language. As China's economic and political influence in the country increases, Argentines perceive a need to learn Chinese language and understand Chinese culture in order to improve their own standing in the world. However, as more Chinese 
immigrants arrive and occupy high(er) rungs of the socioeconomic ladder, racism and discrimination have become serious issues.

What does this mean for second-generation Chinese-Argentines and their feelings towards their heritage language? Because Chinese and other Asian immigrants are discriminated against, they may feel the need to assimilate as much and as quickly as possible, in order to prove their "Argentineness" to their peers. However, because Chinese language is proving to be very important to their nation's future, they also feel pressure to maintain it, or acquire it anew if they have already lost it.

The language attitudes of their immigrant parents also affect second-generation Argentines' feelings about their home language. While many people (including most Chinese) speak of Chinese as a unified dialect, most linguists see Chinese as a language family including many similar but mutually unintelligible varieties, much like the Romance language family. Most Chinese immigrants to Argentina are bilingual (or multilingual) individuals from diglossic 5 societies, where Standard Mandarin (the official language of both Mainland China and Taiwan) is the High (prestigious) variety and the local vernacular (e.g. Taiwanese, Cantonese, or Shanghainese) is the Low (less prestigious) variety. As in many communities, only the High variety is deemed worthy of formal instruction; the programs that teach Chinese as a heritage language in Argentina generally teach only Standard Mandarin, and some parents may choose to speak to their children only in Standard Mandarin for a variety of reasons closely linked to the factors creating the diglossic situations in Mainland China and Taiwan. Thus, when we speak of Chinese language maintenance among the second-generation, what variety of Chinese are we talking about? "Chinese," defined as Standard Mandarin, may be maintained or newly acquired, while regional varieties may be lost. 


\section{ETHNOGRAPHY}

Ethnography is the description of culture (Spradley 1980: 3). In order to describe culture, a researcher must engage with the culture being described by keenly observing how people in the culture interact with each other and with their environment, and also participating in cultural practices to the fullest possible extent, in order to try to understand these practices from the native point of view. This combination of observation and participation, called participant observation, is the primary tool that ethnographers have at their disposal; other ethnographic techniques include interviews and questionnaires (Spradley 1980: 54).

Ethnographic methods have been undervalued in studies of language attitudes. Most commonly, researchers interested in a given community's language attitudes will conduct a matched-guise test ${ }^{6}$ (Feifel 1994: 68). This is unsurprising, as the study of attitudes sprung out of social psychology, where controlled studies are the primary mode of research. However, ethnographic research methods, such as interviewing and participant observation, may be just as insightful as experimental methods. Crystal (2001: 186) defined language attitudes as "the feelings people have about their own language or the language(s) of others;" if language attitudes are based on "feelings" (or, as Hidalgo [1986: 196] put it, "value judgments"), and feelings are expressed through observable behavior, then the ethnographic researcher may be able to infer these feelings through observation of behavior.

The goal of ethnography is to produce what Geertz called "thick description," or the cultural meanings behind observed actions. Geertz defined "thick description" as describing the difference between an involuntary eye twitch and a wink; while they may look the same on the surface, a wink has many layers of cultural meaning attached to it that a twitch does not. By extension, a parody of a wink (a "fake-wink") has layers of meaning that a normal wink does not. Thus, to practice ethnography is to uncover "a stratified hierarchy of meaningful structures in 
terms of which twitches, winks, fake-winks... are produced, perceived, and interpreted" (Geertz 1973: 7).

In the context of the study of language attitudes, a speech act is like a wink. Aside from the meaning that it carries on its own, it also has many meanings attached to it that may not be so obvious. For example, what language variety was the speaker speaking? More importantly for our purposes, why did the speaker choose that variety? How does the speaker feel about this language? How does the speaker's culture perceive that variety? How does the dominant culture in the speaker's place of residence perceive that variety?

One of the major criticisms of ethnography and other qualitative research methods is that these types of methods are insufficiently impartial, compared to (ostensibly) objective quantitative or experimental methods. Indeed, given the subjective nature of observations and interviews, every ethnographic study is colored by the observer's background and past experiences, the rapport between the observer and members of the community, and numerous situational factors that cannot be controlled. However, ethnography can allow the researcher access to dimensions of human behavior and thought that quantitative or experimental methods cannot reach. For example, without ethnography, there would be no way to understand human behavior from the point of view of the actors themselves, as quantitative methods are too limited in scope to answer these questions and experimental methods are always defined according to the cultural background of the researcher (Spradley 1980: 16).

Fortunately, subjectivity can be controlled for. If researchers are to use ethnography, it is important that they critically examine the factors that influence their observations and analyses. Ethnographers must display reflexivity; that is, they must be aware that they are fully embedded in the situations that they observe, and, in writing their ethnographies, must constantly alert 
their readers to this fact (Watson 1987: 35). Throughout this thesis, I aim to problematize my presence in the field as a participant observer, reflecting upon how the relationships that I developed with the Chinese community in Buenos Aires affect my experiences. Additionally, I aim to consider how my diasporic Chinese identity and personal experience of heritage language loss affect my interpretation of experiences in the field.

\section{HYPOTHESES}

Based on the literature on language loss and language attitudes, I have formulated the following hypotheses about heritage language loss in the Chinese community:

Hypothesis 1 - Heritage language loss is occurring in the Chinese community in Argentina. Second-generation Chinese-Argentines face conflicting pressures, some which urge them to abandon Chinese language and culture, and some which urge them to embrace it. These conflicting pressures directly affect the pace of language loss and efforts towards language maintenance.

Hypothesis 2 - The Chinese-Argentine community's shift from Chinese to Spanish matches Fishman's model of language shift. Because members of the group are "displacively [using Spanish] with one another, on the 'inside', for advantages which also obtain even within the weakened and transculturating minority community itself," Chinese language will not survive and complementary schools can do little on their own to reverse this shift (Fishman 1991: 357, emphasis in the original).

Hypothesis 3 - Argentine-born Chinese are learning Standard Mandarin instead of their parents' native variety of Chinese. 
Parents may be passing down Standard Mandarin to their

children, and because of its relative prestige, Standard Mandarin

may survive as a heritage language; however, non-standard

varieties most likely will not, due to a variety of factors including

parent attitudes, lack of reinforcement and opportunities to use

them, and the fact that they are not taught in Chinese

complementary schools.

Hypothesis 4-Students in complementary schools who are most

successful at maintaining the heritage language have a mixed

orientation towards language learning; that is, they mix elements

of Gardner and Lambert's integrative and instrumental

orientations. These students feel strongly connected to Chinese

culture and see proficiency in Chinese as a cultural or economic

asset. Additionally, they see their connection to Chinese culture

and proficiency in Chinese language as serving important personal

goals.

“我是中國人。我是海外中國人。我愛中國。我也愛本地的國家。”

The term "model minority," first used to refer to Asians in the United States, refers to a minority group whose indicators of success, such as high levels of educational attainment, high incomes, and low crime rates, are higher than the population average. Many Asian-Americans (as well as members of other groups to which this label has been applied, such as African immigrants to the United States), have challenged this term because it perpetuates stereotypes, covers up the heterogeneity of the minority group, and implicitly compares the group to other, "less desirable" minorities (McGowan and Lindgren 2006: 338).

The 1.5 generation shares many important similarities with the second generation, though the varying definitions and general impreciseness of the term make it very difficult to generalize about this population (Zhou 1997: 65).

Grimson (n.d.: 6) has shown that the percentage of South American immigrants in Argentina has consistently hovered between 2 and 3 percent of the Argentine population since 1869; many Argentines perceive an increase because the percentage of European immigrants in the population has significantly decreased since then, among other factors.

This type of diglossia, in which the High and Low varieties are genetically related, is sometimes referred to as "digraphia" in the literature (Romaine 1989: 34).

In a matched-guise test, subjects are asked to listen to recordings of voices telling a story and then to judge the personality of the speakers based on the recordings. While they may seem to be different speakers, the recordings were actually done by the same person, who is considered to be a "perfect multilingual" speaker. 
Thus, the context, speaker, and personality of the speaker serve as controls. The judgments that subjects make, therefore, are judgments of the language, not of the speaker (Feifel 1994: 68). 


\section{Immigrant Communities and Language Loss in Argentina}

Heritage language loss is not a new phenomenon in Argentina. Every immigrant group that has settled in the country has eventually abandoned its language for Spanish, the language

of prestige and intergroup communication. However, as in the United States, not all groups lose their languages at the same pace. Some, like the Italian, Spanish, and other European immigrants of the "great wave" that form the basis of Argentine society as we know it today, lost their languages by the first generation; that is, the children of immigrants were largely monolingual in Spanish. Other groups, most notably the immigrants from Great Britain, tenaciously held on to their language and culture for generations by separating themselves from the rest of Argentine society. Korean immigrants, one of the largest and most notable non-Latin American immigrant groups that arrived after World War II, have followed a model that matches Fishman's for the United States: the second generation is dominant in Spanish and weaker in Korean, and chooses to pass on Spanish to subsequent generations.

\section{LANGUAGE LOSS AMONG IMMIGRANTS OF THE “GREAT WAVE”}

During the "great wave" of European immigration in the late $19^{\text {th }}$ and early $20^{\text {th }}$ centuries, millions of migrants from all over Europe (but mainly from Italy and Spain) arrived on Argentine shores, making Argentina the receptor of the second-largest flow of immigrants during this period, after the United States. Immigrants rushed into Argentina's depopulated countryside and developing cities in such large numbers that, for over fifty years, immigrants formed half of the population of the most economically important provinces and almost 70 percent of the population in the capital city of Buenos Aires. While the United States received 
more immigrants, the native born United States population was fairly large, and immigrants came over a long period of time. In Argentina, however, the native born population was fairly small, and immigrants came in large numbers over a relatively short period of time. This is reflected in the census data. In 1914, more than 30 percent of the Argentine population was foreign born; in contrast, in 1910, only 14.4 percent of the United States population was foreign born (Fontanella de Weinberg 1979: 8).

In 1979, Fontanella de Weinberg (1979: 9) wrote, “Today, a little more than half a century after the peak of immigration flows, when a large majority of the Argentine population is composed of direct descendants of immigrants, the vast majority of Argentines only speak Spanish"1. That is to say, heritage languages of the "great wave" were entirely lost by the second generation. This rapid language loss was due to several important factors, including the large number of immigrants relative to the native-born population, the need for a common language among immigrants living in crowded conditions in dense urban areas, and high levels of educational attainment and social mobility (Fontanella de Weinberg 1991: 20).

The education system played a pivotal role in encouraging linguistic assimilation and heritage language loss. Argentine elites saw education as a tool for creating a cohesive national identity among the descendants of immigrants from all over Europe. Thus, in 1884, the government instated a "common, obligatory, and free" education for all youth (Fontanella de Weinberg 1991: 16). All subjects in these newly created public schools were taught in Spanish. Spanish became the lingua franca among students, who came from many different linguistic and cultural backgrounds. The emphasis on Argentine history and civics in the curriculum helped to instill a sense of patriotism and foster a unified Argentine national and cultural identity among students (Fontanella de Weinberg 1991: 17). Thus, it is not surprising that heritage languages were lost by the second generation; the school system actively encouraged students to acquire 
Spanish and become culturally Argentine.

\section{THE ANGLO-ARGENTINE COMMUNITY}

Immigrants from Great Britain were a notable exception to the trend of language loss by the second generation. This is also not surprising, as Anglo-Argentines generally attended their own schools and churches and lived apart from other Argentines in majority Anglo suburbs. British capital flowed to Argentina in the late 1800 s to develop the country's railroads, agriculture, and shipping industries, and skilled British workers followed. These immigrants and their descendants proclaimed themselves to be superior to the local Argentine population and formed their own closed community (Cortés Conde 2007: 41). They settled in specific suburbs of Buenos Aires (many of which have English names, such as Wilde, Hurlingham, and Temperley) and had their own social clubs and churches. Anglo-Argentine children attended private English-language schools where Spanish was not taught, even as an optional subject. Indeed, as a cultural and economic elite whose language was prestigious and economically valuable, the Anglo-Argentines had little incentive to learn Spanish and assimilate into the local Argentine community (Cortés Conde 1993: 24).

This all changed after World War II, when economic ties between Argentina and Great Britain weakened considerably. Anglo-Argentines whose livelihoods depended on the arrival of British capital soon found themselves much less wealthy than before. They had to integrate themselves into the local economy and society to survive. British schools and social clubs opened their doors to wealthy Argentine families, and marriage outside of the community, once rare, became much more common (Cortés Conde 20007: 61).

As a result, Anglo-Argentines are increasingly becoming Spanish-dominant. Younger members of the community are less proficient in English than older members (Cortés Conde 
1993: 67). In Cortés Conde's 1993 study, 66 percent of younger Anglo-Argentines (ages 10-18) surveyed indicated that they spoke mostly Spanish. However, many in this age group indicated that they commonly read in English, and that they understand the written forms of both languages equally well, leading Cortés Conde (1993: 68) to conclude that, for this population, "the English language is not an active skill, actually spoken by the individuals, but a passive skill that they have learned."

Interestingly, the role of English in the Anglo-Argentine community has a parallel in the ethnic Chinese communities of Singapore and Malaysia. Platt (1977: 373) calls Standard Mandarin a "dummy H[igh language]" in these two countries. Though few ethnic Chinese in these regions speak Standard Mandarin, and it is "not in fact used extensively in any domain," it is still seen as a language of high prestige that links the community to a sense of transnational Chinese ethnic identity (Platt 1977: 373). Among Anglo-Argentines, English is the "dummy H;" it is not widely spoken, but still respected among community members for its prestige and its role as a link between Anglo-Argentines and the rest of the English-speaking world.

\section{THE KOREAN COMMUNITY}

In recent decades, Argentina has received sizeable flows of immigration from two nonLatin American regions: South Korea and greater China (Mainland China and Taiwan). As the Korean community is the other sizeable immigrant community of Asian origin in Argentina, and has a longer history in the country than the Chinese, it is possibly the most appropriate point of comparison for the Chinese community. Immigration to Argentina from South Korea began in the mid-1960s, reaching its peak in 1990, when there were 42,000 Korean-born residents in Argentina, mostly settled in the Buenos Aires neighborhoods of Once and Flores (Mera 2005: 11). 
Korean immigrants and Argentines of Korean descent have faced significant amounts of discrimination and racism. Santamaría and Itzcovich’s (2005: 33) analysis of a 2002 set of interview and survey data on discrimination towards Korean and Paraguayan immigrants revealed that Korean immigrants were strongly perceived as being dirty, exploitative, and closed to outsiders.

Mera argues that second-generation Korean-Argentines are caught between two worlds and struggle with their identities: are they Koreans, Argentines, or something in-between? Unlike the United States, which has a long history of so-called "hyphenated" ethnic identities, previous groups of immigrants to Argentina have generally blended into the Argentine "melting pot," shedding most markers of ethnic identity. However, because Koreans look different from most other Argentines, many in the community feel that they will always be outsiders, no matter how well they speak Spanish and how Argentine they act. One of Mera's interviewees gave an example of how this visible difference plays out in everyday life:

I feel Argentine only up to a certain point. Argentines make me feel that I am different, because of my face. Once I was traveling in a taxi and the guys says, 'Where are you from?' I tell him, 'I'm Argentine,' and he says 'No, but from where?' I tell him, 'I was born here.' 'Where were your parents born, then?' [I tell him Korea], then he says, 'Ah!' You see? Your face gives you away. They always make sure you know they can tell the difference. ${ }^{2}$ (Mera 2005: 92)

While there have not been any systematic studies of language loss in the KoreanArgentine community, Mera's interviews and observations suggest that language loss is occurring and that it follows the Fishman model. Despite the existence of community language 
schools that teach Korean (much like in the Chinese community), most children of Korean immigrants speak very limited Korean and often have difficulty communicating with their elders (Mera 2005: 90). This follows Fishman's model very closely: by the second generation, KoreanArgentines are dominant in Spanish and thus are unlikely to pass on the Korean language to subsequent generations.

\section{HOW DOES THE CHINESE COMMUNITY COMPARE?}

The Chinese community is less closed to outsiders than the Koreans or the AngloArgentines; in fact, because Chinese immigrants are spread across the city of Buenos Aires and many open businesses expressly catering to the local population, one could say that they are much more open to outsiders than the other two groups.

The Chinese, along with Koreans and Anglo-Argentines, form part of Argentina's socioeconomic elite. The Chinese are similar to the Koreans in that, despite being economically privileged, they also face racism and discrimination. Many Chinese-Argentines I spoke to told me that overt discrimination and harassment were relatively common; for example, Pan WeiChih, the recent Taiwanese immigrant that I interviewed, often faces bands of cartoneros (people who scavenge for cardboard and other recyclables in garbage bins at night) in his neighborhood who heckle him with cries of “iChinito! iChinito!” (Little Chinaman!). Discrimination and racism against Chinese is often not as overt; many Argentines may be civil to their Chinese neighbors, but privately (or to reporters) may divulge prejudiced views. Some may be more inclined to express their negative feelings when the Chinese presence in the city is made more obvious; for example, many local residents were upset about the erection of a Chinese arch at the entrance to Chinatown (see Section VI).

Like second- and third-generation Koreans, second- and third-generation Chinese often 
feel that they have to prove their "Argentineness" in a society where their physical features make them seem very foreign. The following paragraph, taken from an article from Clarín (Argentina's most widely-read daily newspaper) about Chinese New Year festivities, is very similar to the quote above from a Korean-Argentine that Mera interviewed, in that it exposes one Argentine-born Chinese food vendor's frustration with expectations that he be very familiar with Chinese culture:

"I've never seen so many people together on the streets of Buenos Aires," Mariana, a Peruvian who has studied for two years in Argentina, said with admiration. The young woman finished off a kind of meat empanada that was fried in plain view at a street stand. Then, she bought a small crystal lotus flower that was on sale for a few cents, but she did not succeed in asking about the importance of crystal lotus flowers in Chinese culture. The manager of the stand told her, "My face is Chinese. Nothing more, because I was born in Argentina. Sorry, but I don't know the answer to what you're asking me."3 (Clarín 2009; emphasis added).

The Chinese also share some important similarities with the Anglo-Argentines. As China is quickly becoming one of Argentina's most important economic and political partners, Chinese culture and language have gained a certain cachet. Judging by the ubiquity of advertisements for "business Chinese" and "Chinese culture and language" classes in the subway and in other parts of the city of Buenos Aires, Argentines perceive that Chinese language and culture becoming increasingly important for conducting business and understanding the outside world. Also spread throughout the city are classes for learning English, another world language important in business, politics, and popular culture. 4 The Korean language never had the cachet that English 
has and Chinese is gaining, as Korea has never been a dominant player in Latin America.

1 "Hoy a poco más de medio siglo del momento de mayor aflujo inmigratorio, cuando gran parte de la población argentina es descendiente directa de extranjeros, la inmensa mayoría de los argentinos sólo habla español."

“...yo me siento argentina hasta ahí nomás, la diferencia me la hacen sentir los argentinos, por la cara... me pasó que viajaba en un taxi y te dicen: ‘¿de dónde sos?' y le digo ‘soy argentina', y me dice, 'no, pero de dónde’, le digo 'nací acá', ‘ ¿y tus padres dónde nacieron?’; dice ‘¡ah!' ¿entendés?, la cara te delata, siempre te marcan la diferencia."

“'Nunca había visto tanta gente junta en las calles de Buenos Aires', dijo admirada Mariana, una peruana que lleva un par de años estudiando en la Argentina. La joven apuraba una suerte de empanada de carne que acaban de freír a la vista en un stand. Enseguida tomó una pequeña flor de loto de cristal que se ofrecía por unas monedas, pero cuando quiso saber la importancia de ella en la cultura china no tuvo éxito. 'De chino tengo la cara, nada más, porque soy nacido en la Argentina. Así que disculpame pero no sé lo que me preguntás', fue la respuesta del encargado del stand."

$4 \quad$ One may expect that there would be a similar demand for Portuguese language classes, as Brazil is Argentina's largest trading partner and currently the dominant political power in South America. However, because Spanish and Portuguese are relatively similar and Argentines and Brazilians can understand each other with only slight difficulties, the demand for Portuguese classes is relatively low. 


\section{The Chinese Community in Argentina}

60,000 Chinese immigrants live in this country. They have more than 5,000 supermarkets and $52 \%$ of people shop there. They sell cheaply, raising doubts: Do they pay taxes? Do they unplug the freezers to save money? Is there a Chinese mafia? Truths and myths about a mysterious and enchanting community. ${ }^{1}$

\section{Apocalyptic or integrated?}

Forty-two percent of Argentines think that Chinese immigrants and their descendants have not integrated well into Argentine life, though [these forty-two percent] believe that they will [integrate] at some point, according to the survey that D'Alessio [a market research firm] conducted for Viva.2 (Artusa 2005)

The above quotations come from a May 2005 article in Viva, a magazine accompanying Clarín. Although over five years have passed since the publication of that article, and the Chinese presence in the country has grown, the Chinese-Argentine community is still misunderstood and mistrusted. Discrimination against Chinese-Argentines is widespread, and the media tends to portray them as closed community from an exotic culture conniving to get rich off of local people.

Part of the reason why the Chinese community is so misunderstood is because academics have largely ignored it. Few social science articles about it have been published in Argentina, and almost no books. The article most relevant to the topic of this thesis is Zuzek's (2004) study of the identity and acculturation of young Taiwanese immigrants. Additionally, Sassone and Mera (2007) compared the construction of social identity in Bolivian, Korean, and Chinese neighborhoods in Buenos Aires. Both studies focused on first-generation immigrants, not 
considering the acculturation and assimilation of the second and subsequent generations. Because the Argentine academy has not had any significant engagement with the community, almost all printed material about the Chinese community comes filtered through the lenses of the media, which Argentines acknowledge is always politicized and never impartial. Thus, it is unsurprising that discrimination and stereotypes are so rampant.

\section{HISTORY}

While there are reports of a few single Chinese men who came to Argentina via Peru in the late $19^{\text {th }}$ century, and more who came directly from China in the early $20^{\text {th }}$ century, Chinese immigrants did not come in significant numbers until the 1980s (Yang 1988: 41; Sassone and Mera 2006: 6). In the 1980s, Taiwan was experiencing severe population pressure; this pressure, along with a fear of invasion from communist Mainland China, caused many to emigrate from the island (Yang 1988: 59; Sassone and Mera 2006: 6)3. The Taiwanese came to Argentina as entire families, and many brought enough capital with them to open their own businesses (Sassone and Mera 2006: 6). In the 1990s, when the Argentine government instituted monetary policies that made the peso equal in value to the United States dollar, many more Taiwanese came, opening import-export businesses and supermarkets. Another wave of Chinese immigrants came to Argentina in the 1990s, this time from the booming coastal provinces of the Mainland. Like the Taiwanese who came before, many of these immigrants came with capital to invest in import-export businesses and supermarkets (Sassone and Mera 2006: 6).

According to one of my respondents, after the Argentine economic crisis of 2001, many Taiwanese left the country, either returning to Taiwan or moving on to third countries such as 
the United States. A look at the composition of the Facebook group for the alumni of the school observed in this study revealed that many had gone on to universities in the United States or are otherwise living in the United States, Taiwan, or Canada.

There is virtually no new immigration to Argentina from Taiwan; however, Mainland Chinese are still arriving. According to Mauricio, a young man working in the school I observed who had immigrated to Argentina from Taiwan at a young age, many immigrants from Mainland China come to invest and plan to stay in Argentina indefinitely. Others, however, are living in Argentina temporarily solely to gain citizenship, because they perceive that it is easier for Argentine nationals to settle in countries like the United States and Canada than for Mainland Chinese.

There are some tensions between Taiwanese and Mainland immigrants, largely stemming from stereotypes and political and linguistic differences. However, most people in the Chinese-Argentine community that I spoke with on the subject felt that these tensions were minimal. Possible explanations for this include the fact that many Argentines are not aware of these differences and refer to all immigrants of Chinese origin as chinos, and the fact that many Taiwanese have returned to Taiwan or moved on to third countries just as Mainlanders are beginning to arrive in large numbers. Furthermore, some feel that there is a pan-Chinese identity that transcends political differences; Mr. Chang, the Taiwanese teacher's assistant in the classroom I observed, said that tensions between Taiwanese and Mainlanders was a "bad habit," because it is like "discriminating against your own people."

\section{POPULATION SIZE}

There are no definitive data on the size of the Chinese population in Argentina. The Argentine census collects data on the country of origin of immigrants, but those who were born 
in Argentina are counted as Argentine, making no note of their ethnic origin. The 2001 Argentine census indicates that there are slightly over 4,00o immigrants from Mainland China and around 3,500 from Taiwan (Instituto Nacional de Estadística y Censos 2001).

However, there may be many more Chinese immigrants in the country than the census indicates. According to an article that appeared in Clarín in 2009, there are around 70,000 immigrants of Chinese origin in Argentina; however, this article neither cites the source of the numbers nor indicates whether this figure includes both immigrants from both Mainland China and Taiwan (Bilbao and Farber 2009). The 2010 Argentine Census results, once compiled and published, may provide a more definitive estimate of the number of Chinese immigrants in the country.

Sassone and Mera (2006: 6) speculate that new restrictions on immigration and the presence of undocumented immigrants may be the reason why there is no exact count of Chinese in the country. According to Argentine immigration authorities, in 2004 there were over 13,00o Chinese nationals illegally resident in the country, compared to fewer than 3,000 legal residents. A representative of the Embassy of the People's Republic of China has said that many Mainlanders enter Bolivia with valid visas and illegally cross into Argentina from there (Artusa 2005).

\section{SETTLEMENT PATTERNS}

While there are some immigrants of Chinese origin in the provinces of Buenos Aires and Santa Fe, most have settled in the nation's capital, the Autonomous City of Buenos Aires 4 . Unlike in many North American cities, Chinese immigrants are not concentrated in any one district. Some claim that those who run supermarkets live inside them; considering that Chinese 
supermarkets are spread throughout the city, this would mean that there are Chinese residents in almost every neighborhood (Artusa 2005).

Most businesses catering to the Chinese community are located in a four-block area in the upper-middle class, largely residential neighborhood of Belgrano. In the Barrio Chino, or Chinatown, there are supermarkets carrying Chinese foods, as well as hair salons, video rental stores, churches and temples, and schools that teach Chinese as a heritage language to immigrant children and children of immigrants. In addition, there are many businesses catering to the local Argentine community, such as curio shops and restaurants serving Chinese food adapted to local tastes. On weekends, the neighborhood is a popular destination for Argentines of European extraction, who come to shop for trinkets and eat dishes like chop suey and egg rolls. Thus, Chinatown not only provides services for the Chinese community, but also serves as an introduction to Chinese culture for non-Chinese local residents. Sassone and Mera (2006: 11) argue that this "dual orientation: an intra-communal one and an extra-communal one" 5 make Buenos Aires' Chinatown more like Chinatowns in the developed world than like ethnic or immigrant communities within Argentina, which tend to serve the ethnic community exclusively.

\section{THE CHINESE PRESENCE IN BuENOS AIRES}

Many Chinese immigrants have dedicated themselves to opening neighborhood supermarkets that cater to the local Argentine community. Chinese-run supermarkets have become so ubiquitous in the city that el chino ("the Chinese" or "the Chinaman") has become synonymous with "supermarket" (Moure 2009). These supermarkets are known for their cheap prices, longer hours, and convenience; a middle-class Argentine family might buy the majority 
of its food at a large supermarket chain like Disco or Carrefour, but would make a quick run to el chino for snacks and missing ingredients, especially if the large supermarket chain is further away or not open for business.

Although Chinese-run supermarkets are very popular with busy urban families, many Argentines do not trust them. Some claim that they unplug the freezers at night to save money, that they do not pay their employees fair wages, or that they do not pay taxes or are reimbursed for taxes by the Chinese government. Representatives of the Chinese merchants' association have vehemently denied these claims, saying that Chinese supermarkets keep their prices low by buying in bulk and using a different business model from most local supermarkets (Artusa 2005).

The ubiquity of Chinese supermarkets has given rise to many Chinese-run businesses that serve them, such as businesses that specialize in selling and repairing freezers and cold cut slicers. The vast majority of Chinese immigrants who do not own their own businesses work for another Chinese immigrant (Zuzek 2004: 27).

Another way in which Chinese culture and language are present in Buenos Aires is through the ubiquity of advertisements for Chinese-language classes. Throughout my fourmonth stay in the city, I noticed that many subway cars had advertisements Chinese language classes for beginners. I was fortunate to become good friends with Pan Wei-Chih, a recent Taiwanese immigrant who teaches in several of these language schools, and also gives private lessons. He told me that the majority of his students think that "Chinese is the language of the future" and that learning it would be beneficial to their careers.

\section{RELATIONSHIP WITH OTHER ARGENTINES}

Because most Chinese immigrants work within the community, the community itself is 
relatively closed. Many Chinese immigrants speak Spanish poorly, and because working within the community reduces the need to acquire more advanced Spanish, interactions with nonChinese tend to be minimal. This lack of interaction has given rise to stereotypes and distrust among non-Chinese. One common stereotype is that Chinese immigrants are extremely wealthy businesspeople who compete on unfair terms and who are not willing to associate with the rest of the population (Moure 2009).

The perception that Chinese immigrants do not conduct business fairly is an especially touchy subject. As stated previously, some Argentines believe that the Chinese do not pay taxes (or that the Chinese government reimburses them for taxes), that they unplug their freezers at night to save money, or that they do not pay fair wages (Artusa 2005). Korean immigrants are also stereotyped as unfair businesspeople; however, Koreans are additionally perceived as being exploitative towards migrant workers from neighboring Latin American countries. Korean immigrants, who came to dominate the Argentine textile industry, are frequently said to employ undocumented Bolivian, Paraguayan, and Peruvian workers. News reports of labor abuses in Korean-owned textile factories have often portrayed "the Koreans" as "exploiters"6 and slave drivers (Courtis 200: 57). As the majority of Chinese-owned supermarkets employ only other Chinese, the community is generally not seen as exploitative. However, the fact that they tend to employ only other members of the community may reinforce the perception that the Chinese community is closed to outsiders.

There are also some "positive" stereotypes of Chinese people and Chinese culture in Argentina. Many Argentines think that Chinese culture is exotic and interesting, and that consuming it, by eating Chinese food or buying traditional Chinese objects at stores in Chinatown, makes them more cosmopolitan and worldly. Other positive stereotypes relate to the aforementioned “model minority myth” (see Section III); Chinese students are stereotyped as 
being especially studious and well-behaved, and Chinese business owners are believed to be tireless workers7 . One man, interviewed by an Agence France-Presse reporter about the arch in Chinatown, had this to say:

PASSERBY: It seems to me that they're people who work every day. From morning to night. ${ }^{8}$ (Agence France-Presse 2009)

\section{LANGUAGE ATTITUDES OF THE CHINESE COMMUNITY}

Knowledge of the linguistic diversity of greater China and the language attitudes that Chinese immigrants bring with them upon immigrating to other countries is essential for understanding bilingualism and language shift in the Chinese diaspora. Chinese immigrants are usually speakers of several varieties of Chinese, and hold conflicted attitudes towards these different varieties as a result of the social and political environment in which they grew up.

While many people, Chinese and non-Chinese alike, believe that there is one Chinese language with several dialects, linguists have disputed that belief, arguing instead that there are several distinct groupings of varieties of Chinese, and that within those, there are numerous subvarieties. The primary groupings of varieties of Chinese (hereafter referred to as "dialect groups") are Mandarin, Yue, Wu, Min, Gan, Xiang, and Hakka. Within these groupings are varieties commonly known as Chinese dialects. For example, Cantonese is a dialect in the Yue group, and Standard Mandarin is a dialect in the Mandarin group (Ingulsrud and Allen 1999: 14).

Having come from Taiwan as well as various regions of Mainland China, the Chinese community in Argentina is linguistically very diverse. Standard Mandarin is the lingua franca among immigrants. These immigrants speak a number of different dialects of Chinese languages 
as their native languages, including Taiwanese (a dialect of Southern Min), Fuzhou dialect (a dialect of Eastern Min), and Shanghainese (a dialect of $\mathrm{Wu}$ ).

Standard Mandarin, based on but not equivalent to the Beijing dialect, is the official language of both Mainland China and Taiwan. Both use Standard Mandarin as the medium of instruction in all schools, for students of all dialect groups. In addition, Standard Mandarin is the language of most mass media and is used as a lingua franca for communication between dialect groups.

Both governments have used the promotion of Standard Mandarin for political purposes, although to very different ends. After the Chinese Civil War came to a halt in the 1940s, both governments saw the use of Standard Mandarin as a tool to create a unified nation-state. As a significant majority of Mainland Chinese are speakers of varieties of Mandarin (which may or may not be intelligible with Standard Mandarin), and because the local vernacular in Beijing, the Chinese capital for over a millennium, is also a variety of Mandarin, Mandarin was clearly the preferred base for a constructed national language (Ingulsrud and Allen 1999: 15). Standard Mandarin as it exists today in Mainland China and Taiwan is a slightly modified form of the Beijing vernacular. While the two countries maintain their own standards, there are few substantial differences between Mainland Standard Mandarin and Taiwanese Standard Mandarin.

\section{LANGUAGE POLICY AND ATTITUDES IN TAIWAN}

Taiwan's small size belies its linguistic diversity, a result of several waves of settlement and colonization. The native inhabitants of Taiwan speak several Austronesian languages (Lewis 2009). Settlers from southern China brought dialects of Southern Min (which developed into the variety currently known as Taiwanese) and Hakka. During the Japanese colonial period 
(1895-1945), the government strongly encouraged the inhabitants of Taiwan to learn and speak Japanese; after a decade of experimentation with using Taiwanese to teach Japanese, the school system switched to complete Japanese immersion, and entire families were lauded and awarded for being "families that speak the national language often,"9 with "national language" referring to Japanese (Hong 1992: 41).

In 1945, Taiwan was returned to Chinese rule. The Kuomintang (KMT or Nationalist Party), in forming its language policy in Taiwan, borrowed heavily from the Japanese, reappropriating the term "national language" to refer to Standard Mandarin. ${ }^{10}$ Taiwanese, Hakka, and the aboriginal languages were called fangyan $^{11}$, or local dialects (Sandel 2003: 529). Hong (1992: 42) argues that the use of the term "national language" is indicative of the influence of the nationalism of imperial Japan on KMT language policies. Indeed, the KMT, like the Japanese, explicitly linked speaking the national language with loyalty to the government, and declared that speaking Standard Mandarin would be important for Taiwan when the KMT took back the Mainland from the Communists and reunified China (Sandel 2003: 529).

Speaking Standard Mandarin also became a necessity for communication within the island. In 1949, at the end of the Chinese Civil War, KMT sympathizers from many different regions of China were pushed out of the Mainland by the Communists and settled en masse in Taiwan. These Mainlanders, who in Taiwan are called waishengren"12, or "people from other provinces," concentrated themselves in Taipei and other parts of northern Taiwan. The role of Standard Mandarin as the lingua franca used between waishengren and benshengren ${ }^{13}$ (people whose ancestors had migrated to Taiwan much earlier; literally "people from this province”) explains why Standard Mandarin has made more inroads in the north of the island. Benshengren were the majority in the south; thus, Taiwanese is still much more widely spoken in southern counties. 
The government enforced a strict Standard Mandarin-only policy in schools. After kindergarten, which was taught in both Taiwanese or Hakka and Standard Mandarin, all other grade levels were taught exclusively in Standard Mandarin. Students who spoke Taiwanese or Hakka in class received corporal punishment or humiliation; a common practice was punishing offenders by making them wear a large "dog placard" that said "Please speak [Standard] Mandarin" (Sandel 2003: 536). In addition to schools, the language policy was also applied in the media; on radio and television, only Standard Mandarin was to be used (Sandel 2003: 547).

Upon democratization in the late 1980s, the Taiwanese government's language policy changed dramatically. Taiwanese and Hakka could be used on radio and television. In the 200os, schools began teaching Taiwanese and Hakka as separate subjects, although Standard Mandarin was used in all other contexts. However, the effects of the KMT government's restrictive language policy are widely felt. Taiwan is now a diglossic society, with Standard Mandarin being the High language and Taiwanese, Hakka, or aboriginal languages being the Low languages. Many Taiwanese who were educated in the era in which use of non-Standard Mandarin varieties was heavily sanctioned held negative attitudes towards the Low language varieties spoken in their homes. This affected the way that they spoke with their own children; Sandel et al. (2006: 135) found that many parents used Standard Mandarin with their children, and that this "choice... may be driving language shift among children.” Indeed, many younger Taiwanese, waishengren and benshengren alike, are dominant speakers of Standard Mandarin and speak Taiwanese or Hakka haltingly at best (Sandel et al. 2006: 143). Those who do speak Taiwanese or Hakka are often embarrassed to speak it or even admit to speaking it. When I was studying in Taiwan, I asked several university students to list what languages they speak. Almost everyone listed "Chinese," meaning Standard Mandarin, and did not reveal that they also spoke Taiwanese or Hakka until after further questioning. 
What does the legacy of KMT language policy mean for the Chinese community in Argentina? According to one informant, most Taiwanese immigrants to Argentina are from the south of the island, and thus commonly speak Taiwanese. Indeed, during my observations, I noticed that those who emigrated from Taiwan as adults spoke amongst themselves almost exclusively in Taiwanese. However, if Taiwanese parents abroad are like the parents in Taiwan that Sandel observed and interviewed, they may prefer to speak with their children in Standard Mandarin. This is especially likely since Standard Mandarin is necessary for communicating with Mainland immigrants in the community. Furthermore, with Mainland China's rising influence in Argentina and Taiwan, parents may perceive that it is in the best interest of their children to master Standard Mandarin before Taiwanese or in place of Taiwanese. Thus, it is unsurprising that the community language schools in Buenos Aires (most of which were set up by Taiwanese immigrants) teach exclusively in Standard Mandarin, meaning that if Argentineborn Chinese were to gain exposure to academic Chinese at all, it would be taught in Standard Mandarin. Thus, if Taiwanese immigrant parents prefer that their children acquire Standard Mandarin and prefer to speak to them in Standard Mandarin at home, it is unlikely that Taiwanese will be passed on to the second and subsequent generations.

\section{LANGUAGE POLICY AND ATTITUDES IN MAINLAND CHINA}

While it could be argued that the KMT tried to eliminate local vernaculars through its promotion of Standard Mandarin, the Communist government on the Mainland has tolerated bilingualism to a greater extent. Standard Mandarin, called Putonghua ("common/basic language"), is the language of government and is used in schools and in most broadcast media. While policymakers had initially hoped that Standard Mandarin would replace local vernaculars 
at some point in the future, over time the relationship between Standard Mandarin and nonstandard languages has been redefined as one of complementarity: the government promotes Standard Mandarin as a national lingua franca, but quietly tolerates use of local vernaculars among people of the same regional origin (Guo 2004: 49). Use of local vernacular or Standard Mandarin with a strong regional accent is often preferred, especially for politicians who wish to emphasize their connection with their home regions; even national revolutionary leaders like Mao Zedong and Deng Xiaoping insisted on speaking heavily accented Standard Mandarin (Erbaugh 1995: 82). In schools, the government "tacitly supported" bilingual education, and unlike in Taiwan, students are encouraged to speak Standard Mandarin in schools but are not punished for speaking their native dialects (Erbaugh 1995: 83).

As in Taiwan, the result of the central government's promotion of Standard Mandarin as a lingua franca is that most of Mainland China is now diglossic, with Standard Mandarin being the High variety and local vernaculars being the Low varieties. However, possibly due to tolerance and tacit promotion of local vernaculars and local culture, Standard Mandarin is not always the language of prestige in all areas and in all situations. Additionally, because of China's historically uneven economic development, certain local varieties are considered "strong dialects"-most often the Shanghai variety of Wu and Guangzhou/Hong Kong variety of Yueand thus are considered varieties of prestige, even among Chinese from other regions (Ingulsrud and Allen 1999: 17).

However, as the promotion of Standard Mandarin continues and the standard variety makes inroads even in "strong dialect" regions, the status of local vernaculars is changing. In his matched-guise study of language attitudes in Shanghai, Gilliland found that while native Shanghai residents rated Standard Mandarin more highly than the Shanghainese in terms of social prestige, as expected, they did not rate Shanghainese more highly than Standard 
Mandarin in terms of group solidarity. The author hypothesizes that this may be due to “[Standard Mandarin's] increasing presence in [low] variety domains;" that is, native Shanghai residents are increasingly using Standard Mandarin in situations where Shanghainese may have been more common before (Gilliland 2006: 92).

Since even Chinese from "strong dialect" regions are increasingly using Standard Mandarin in domains previously reserved for their local vernaculars, it may be safe to assume that this shift to Standard Mandarin happening with greater alacrity in regions with "weaker" vernaculars. Mainland immigrants to Argentina come from many regions, including “strong dialect" regions like Shanghai and "weaker" vernacular regions like Fuzhou (where a variety of Eastern Min, not mutually intelligible with the Southern Min of Taiwan, is spoken).

What does this mean for the maintenance of these varieties of Chinese in the ChineseArgentine community? Have Mainland parents of the same regional and linguistic background started speaking with their children in Standard Mandarin instead of their local vernacular? Because Mainland Chinese immigrants speak many different vernaculars, are these vernaculars less likely to be maintained than Taiwanese because there is a much smaller population of speakers in Argentina?

\section{LANGUAGE USE AMONG CHINESE IN ARGENTINA}

As previously stated, because the immigrant community is diverse in Chinese regional origin, Standard Mandarin is used as the lingua franca. However, I have observed that local varieties of Chinese are used even in situations where one may expect a variety of higher prestige to be used. For example, at the community language school where I did my fieldwork, the administrators, all Taiwanese, used Taiwanese amongst themselves almost exclusively, including when dealing with official matters. Similarly, Mainland immigrants from the same 
regional background tend to use their local variety instead of Standard Mandarin. However, as most of my interactions with Chinese in Argentina have been with Taiwanese, I have not been able to observe instances where a local vernacular from the Mainland is used in a situation where an outside observer would believe that Standard Mandarin would be preferred.

Immigrants' command of Spanish is generally minimal. Mrs. Lin, the teacher of the community language school class that I observed, told me that most Chinese immigrants came to Argentina to open shops, restaurants, and other businesses, and thus have little time for Spanish lessons and often only know enough Spanish for their jobs. I asked that she respond to some of my questions in Spanish, and she spoke haltingly, with a strong accent, basic vocabulary, and many grammatical errors. In my experiences shopping at Chinese-run supermarkets, the shopkeepers either did not talk to customers beyond giving the total cost of the transaction, or hired local women to work as cashiers and talk with customers. At Chinese restaurants, waiters and waitresses invariably greeted me in Standard Mandarin first, and took my order in Standard Mandarin; however, I’ve observed Argentines having difficulty making their orders understood in Spanish.

While most immigrants speak little Spanish, it is the preferred language of their children, who acquire some amount of Standard Mandarin in schools that teach Chinese as a heritage language and may have some grasp of their parents' native variety of Chinese. Argentine-born Chinese that I observed at the language school where I did my fieldwork and elsewhere in Buenos Aires almost always spoke to each other in Spanish.

I do not know about the general level of Chinese (Standard Mandarin or otherwise) proficiency among Argentine-born Chinese. However, if their command of Chinese is weak, and their parents' command of Spanish is also weak, communication difficulties may arise. In their study of children of immigrants in the United States, Portes and Rumbaut argue that the 
communication barriers that arise when children abandon the language of their parents for the dominant language and the parents are not proficient enough to accommodate create what they call "dissonant acculturation," which results in weakened parental authority. There may also be "role reversal and intergenerational conflict" because children are often required to interpret for their parents in spaces situations where the dominant language is used, such as at the hospital or when dealing with government agencies (Portes and Rumbaut 2001: 77). Does this sort of “dissonant acculturation" occur in the Chinese-Argentine community?

\section{CHINESE COMPLEMENTARY SCHOOLS IN BUENOS AIRES}

Chinese immigrants all over the world have set up schools that teach Chinese as a heritage language to the children of the community. Kenner (2004) terms these schools "complementary schools" because they are complementary to the mainstream school system, teaching subjects not available in mainstream schools after normal school hours (152). Chinese complementary schools generally operate on weekends or after school hours on weekdays, and primarily serve second-generation students, although some schools may also serve third- and fourth-generation students and students with no Chinese background. Chinese complementary schools have existed in some form in the United States since as early as the mid-180os; as the Chinese-Argentine community is far newer, these schools have only appeared in the last two decades (Chao 1996: 7).

Despite their ubiquity in Chinatowns around the world, and their importance as primary cultural institutions in these ethnic communities, there have been few significant social scientific investigations into how these schools work and what roles they play in Chinese communities. The few researchers who have examined complementary schools closely have found that these schools are integral to the life of the community. In her work on the Chinese immigration to 
Spain (which is about as recent as the Chinese immigration to Argentina), Nieto (2007: 14) found that by establishing complementary schools, social organizations, and Chinese-language newspapers, the elites among the Chinese immigrants were able to create a sense of collectiveness that linked the Chinese to each other and to the nationalist projects of Mainland China and Taiwan. The schools serve as important transmitters of Chinese identity, and, to borrow a term from Benedict Anderson, as tools central to the imagining of the Chinese community in Spain as an extension of the Chinese nation (Nieto 2007: 110). Thus, the schools are not only physical spaces where members of the community congregate and interact with each other, but are also a central pillar of a metaphorical space for the Chinese collectivity in Spain.

Complementary schools in Argentina serve a similarly central role in the Chinese community there. Almost all immigrant parents (94 percent, according to Zuzek [2004: 27]) and significant numbers of Argentine-born Chinese parents send their children to these schools. Furthermore, two of the most commonly advertised schools were founded by Chinese religious organizations and share physical space with these organizations, further cementing the schools' role as establishments integral to the community. Thus, I would argue that any serious social scientific study of the Chinese community in Argentina should take these schools into account.

The schools most commonly advertised in local Chinese magazines are Academia HsinYi (the school featured in this thesis), Instituto Wei-Teh, and Instituto Roosevelt. Both Academia Hsin-Yi and Instituto Wei-Teh are located in Chinatown and are run by religious institutions (Hsin-Yi by the Hsin-Yi Taiwanese Presbyterian Church and WeiTeh by the Chin-Long Buddhist Temple), while Instituto Roosevelt is located in the Flores neighborhood and is not affiliated with any religious group. Another difference is that Hsin-Yi and Wei-Teh are run by Taiwanese and teach the traditional Chinese 
characters used in Taiwan, Hong Kong, Macau, and most overseas Chinese

communities, while Roosevelt is run by Mainlanders and teaches the simplified

characters used in Mainland China, Malaysia, and Singapore.

One of the goals of this thesis is to compare Chinese complementary schools in Argentina with those in the United States. Chinese complementary schools in the United States face a number of challenges in teaching the heritage language to students, ranging from student apathy to lack of teacher training. Most teachers in these schools are parent volunteers who are not certified in teaching and are not interested in teacher certification; furthermore, because of lack of demand, programs for certifying complementary school teachers are almost non-existent (Peng 1996: 48). The lack of certification and familiarity with American pedagogical practices is one of the contributing factors to the high dropout rate in these schools. Second-generation students are often frustrated by traditional Chinese teaching methods, which require rote memorization and recitation; coupled with the time commitment on weekends, students "often do not see any rewards for themselves" in attending complementary Chinese schools (Wang 1996: 64). What kinds of problems do Chinese complementary schools in Argentina face, and how are they similar to or different from those faced by schools in the United States?

\footnotetext{
$1 \quad$ "En el país viven 60.000 inmigrantes chinos. Tienen más de 5.000 supermercados y el $52 \%$ de la gente hace sus compras allí. Venden barato y surgen dudas: ¿Pagan impuestos? ¿Desenchufan la heladera para ahorrar? ¿Existe la mafia china? Mitos y verdades de una comunidad que encierra encanto y misterio.”

$2 \quad$ “Apocalípticos o integrados? - El 42 por ciento de los argentinos piensa que los inmigrantes chinos y sus descendientes no se han integrado bien a la vida en la Argentina aunque cree que lo harán en algún momento, dice la encuesta para Viva de D’Alessio."

3 This is comparable to the reasons why South Koreans emigrated in the 1960s: population pressure and unstable relations with North Korea. Both countries were also ruled under repressive military dictatorships at the time, another possible "push factor" encouraging residents to emigrate (Mera 2005: 10).

4 The Autonomous City of Buenos Aires is separately administered from the Province of Buenos Aires which surrounds it.

5 "una doble orientación: una intracomunitaria y otra extracomunitaria"
} 
"Los coreanos;" "explotadores"

This stereotype may be informed by the fact that Chinese-run supermarkets are often open for much longer hours than other stores, and also tend to be open on Sundays (when most stores in Argentina are closed). "Me parece que son personas que laburan todos los días. Desde la mañana hasta la noche."

9 “國語常用家庭”

10 "National language" in both Japanese and Chinese is written with the same characters: “國語.”

11 方言

12 外省人

13 本省人 


\section{Academia Hsin-Yi: An Ethnographic Study}

The bulk of this thesis is written on the basis of ethnographic fieldwork that I conducted at Academia Hsin-Yi, one of two Chinese complementary schools in Buenos Aires Chinatown. While I had intended to observe high school classes and interview second-generation teenagers about their language attitudes, I only had access to a first-grade classroom, a first-generation classroom teacher, a "1.5 generation" assistant teacher, and a recent immigrant who teaches Chinese to Argentines with no Chinese background. However, through synthesizing analyses of the observations and interviews that I did get, I have been able to further my understanding of the community's attitudes towards language and draw some tentative conclusions about the nature of heritage language loss in Argentina.

\section{DESCRIPTION OF THE FIELD}

The Chinatown of Buenos Aires is located in the heart of the upper middle class residential and shopping district of Belgrano, about half an hour by subway from the financial and political center of the city. As in many Chinatowns around the world, the entrance to Chinatown (at the intersection of Arribeños and Juramento streets, across the tracks from a busy commuter rail station) is marked by a decorative arch, known in Chinese as a pailou (see Appendix 1, Figure 1). The arch, a gift from the government of Mainland China worth USD 400,000, was constructed in 2009 (Russo 2009; Agence France-Presse 2009). The marble stele at the bottom of the arch describes its significance in Spanish and in simplified Chinese characters (a clear signal that it was erected by Mainlanders, as the Taiwanese would have used traditional characters). The Spanish text (very similar to the Chinese) says: 
The Chinese community donates this arch with affection on the occasion of the Bicentenary of the May Revolution to the beautiful City of Buenos Aires and the great Argentine people in gratitude for the generosity and love offered to Chinese immigrants, with the hope that the Chinese-Argentine friendship will endure for generations. ${ }^{2}$

While this arch is nominally a token of friendship, many Buenos Aires residents are unhappy with its existence. Many feel that it is a sign of a Chinese invasion, a visual reminder of China's power in the world and influence in Argentina (Agence France-Presse 2009). A reporter for the national newspaper La Nación asked a passerby about her feelings on the arch:

PASSERBY: It's horrifying. REPORTER: Why?

PASSERBY: Because it gives more power or pride to the Chinese. 3 (Russo 2009)

Another neighborhood resident put it this way:

RESIDENT: It's outrageous that citizens of another country can come, just like that, and put an arch at the beginning of a street. ${ }^{4}$ (Russo 2009)

Clearly, there is some amount of xenophobic animosity directed towards Chinese immigrants and Argentines of Chinese descent. On several occasions, I have seen the stele defaced with eggs. On other occasions, the gold text was stained with black paint, and then covered up with flyers that said, "Who killed this tree?"5 (see Appendix 1, Figure 2). Other fliers 
in the vicinity explained the situation: local residents were angry that several trees that lined that block of Arribeños Street were cut down to erect the arch. Is this truly a question of environmental preservation and neighborhood aesthetics, or are local residents using criticisms of the arch as a thinly veiled proxy for their sentiments towards the Chinese presence in the city?

\section{ENTRY INTO THE FIELD}

During my first few visits to Chinatown, I walked around the four-block area looking for signs for complementary schools. As there were no obvious signs, I went to one of several supermarkets selling Chinese groceries and bought copies of the major Chinese magazines in Argentina-Info Mundo, Semanario Nuevo Continente, and Horizonte Chino ${ }^{6}$ (see Appendix 1, Figure 3). After flipping through pages of advertisements and articles, I found the contact information for three different schools. I decided to contact Academia Hsin-Yi and Instituto Wei-Teh for permission to observe, as both were in Chinatown and thus very much embedded in the community.

After an unsuccessful attempt to get permission to observe at Instituto Wei-Teh, I turned to Academia Hsin-Yi. The school, it turned out, was operated by the Hsin-Yi Taiwanese Presbyterian Church, and was located in the same building. On the outside of the building was a prominent blue banner written in traditional Chinese characters advertising three religious services on Sundays: first in Taiwanese, then in Spanish, then in Standard Mandarin.

Several interactions with school staff in broken Standard Mandarin led me to Paulina, a second-generation Taiwanese-Argentine receptionist. I spoke with her briefly about the possibility of conducting my fieldwork at the school; she told me to return the next 
week to speak with the administration. The next week, I met Mauricio, another administrative assistant in the school, who moved to Argentina from Taiwan at the age of 11. He showed me around the facilities of the school, introduced me to the school administration and church elders, and talked to me about the history of the school and the Chinese-Argentine community. According to Mauricio, the school serves 300 students and is the second-largest Chinese complementary school in Buenos Aires. Aside from teaching Chinese as a heritage language to the youth in the community, it also teaches Spanish to Chinese immigrants and Chinese as a foreign language to non-Chinese Argentines.

Classes meet on Saturdays from 9 AM to 4 PM. Students are divided into grades by age, according to the Taiwanese school system7. The school matches the Argentine public school system in that the academic year runs from March to December. Unlike many other Taiwaneserun complementary schools in Argentina and the United States, which use texts provided by the Taiwanese government for use exclusively in complementary schools overseas, Academia HsinYi uses the same language arts texts as primary and secondary schools in Taiwan. Although I was unable to ascertain why the school chooses to use these texts, it may in part be a response to the phenomenon of return migration to Taiwan; studying the same curriculum using the same textbooks would make it easier for students raised in Argentina to adapt to the Taiwanese education system.

As is customary in Taiwanese schools, the school refers to Standard Mandarin as the national language (Guoyu) and traditional Chinese characters as national characters $\left(g u o z i^{8}\right)$. At one point, I witnessed a teacher asking a student to re-do his work because he wrote in the simplified characters used on the Mainland instead of in traditional characters. This reflects the influence of Taiwanese education policy, as simplified characters are frowned upon in Taiwanese schools. 
The Academia does not teach varieties of Chinese other than Standard Mandarin. I have not witnessed any teachers sanctioning their students for speaking in non-standard varieties, as most students speak either in Standard Mandarin or in Spanish. However, among themselves, teachers tend to speak Taiwanese.

Academia Hsin-Yi takes up the majority of the church building. The first floor is home to the administrative offices of the school and the church, rooms for kindergarten classes, as well as a small auditorium-cum-lunch room for the students. In the first floor lobby, the school has placed announcements, examples of exemplary student work, and short biographies of all the teachers and administrative staff. There are also boards that indicate which team won which intramural soccer game. Students are organized into teams by grades (each team only plays teams close in age), and there is a game every week.

While Mauricio showed me around the first floor, the kindergarteners were let out for recess. About 50 young children rushed out of the classrooms and into the lunch room for horseplay and gossip. All of the screaming and yelling was conducted in Spanish. I asked Mauricio about this, and he replied that almost all of the students spoke Spanish to each other outside of class.

We went up to the second floor as classes for primary school students were resuming after recess. I noticed that all of the students stood up when the teacher entered the room, and did not sit down until they were instructed to do so. Mauricio said that although they did not do this in Argentine schools, Academia Hsin-Yi insists on retaining this Chinese custom.

Classrooms for high school heritage language students were on the third floor, as were the church facilities and the classrooms for teaching Chinese as a foreign language. As Mauricio and I entered the chapel, we met the retired former principal of the school, who is still very 
active in the church. Mauricio introduced me and my project to the principal in Taiwanese. The principal then spoke with me briefly (in Standard Mandarin) about my project.

Mauricio explained the different Sunday services which I saw advertised outside. The earliest service is in Taiwanese, which is attended mostly by Taiwanese immigrants. The second service, in Standard Mandarin, is mostly attended by immigrants from the Mainland. The third service, in Spanish, is mostly attended by second-generation Chinese-Argentines. The Spanish service differs from the Taiwanese and Standard Mandarin services in that it is geared towards youth and makes use of musical instruments. While students in the school are not necessarily parishioners of the church, they are invited and encouraged to attend services and go on youth retreats. The curriculum of the school is mainly focused on language learning, although later on I did observe one class session in which a Sunday school teacher came in the classroom and asked students to color in a nativity scene from a coloring book.

Mauricio and I went down to the first floor office to get approval for my project from the current principal. Mauricio explained my project to the principal (in slow Standard Mandarin, presumably so that I would understand); the principal then replied to Mauricio in Taiwanese, and they continued speaking in Taiwanese for some time. The principal then turned to me and told me (in Standard Mandarin) that I should bring a letter from my project advisor; they would attempt to find a teacher willing to let me observe, and I would be able to begin class observations in two weeks. Mauricio told me that I should come again the next week, in order to observe the intramural soccer match.

I accepted Mauricio's invitation to the soccer match and went to the school again the next weekend. Before heading up to the rooftop soccer field, I spoke with Mrs. Ma, the director of educational affairs, about my project. She asked me (in Standard Mandarin) if I would be fine 
with coming again next week to interview high school freshmen in the five minutes that they had between periods. I tried my best to explain that what I had intended to do was observe a class for several weeks, but much was lost in translation. She told me, matter-of-factly, that she did not understand the point of my project. "Everyone knows that the students all speak Spanish outside of class, anyway," she said. Her blunt statement frustrated me, but I eventually managed to convince her to let me observe a class the next week.

On my way up the stairs, I ran into Mauricio, who was wearing a dress shirt with no tie and a whistle around his neck. He told me that he was refereeing the soccer game, which was beginning soon. I followed him up to the rooftop "soccer field," which was actually an allpurpose recreational space with a concrete floor and a basketball hoop at each end. He introduced me to the two physical education teachers, Roberto and José Luis, who are both Argentine-born Chinese men in their early 20s. Roberto and José Luis spoke mostly in Spanish to each other, to Mauricio, and to me. However, they code-switched ${ }^{9}$ at times, peppering their Spanish with a word or phrase in Standard Mandarin. I noticed that the papers that they had on their clipboards were all in Chinese, meaning that they could read and write in that language.

When I arrived, there were teams of boys playing basketball. On the sidelines were several groups of girls talking to each other. Almost everyone was speaking to each other in Spanish, except the group of three girls closest to me, who spoke to each other exclusively in Standard Mandarin, and another group of girls that was code-switching (approximately 70 percent Spanish and 30 percent Standard Mandarin). Interestingly, there were several words that almost everyone on the field said in Standard Mandarin. Most of the students referred to Mauricio, Roberto, and José Luis as laoshi ${ }^{10}$, Standard Mandarin for teacher, although some preferred profe, a shortened form of Spanish profesor. Additionally, when referring to the soccer game that day, between the fifth and sixth grade teams, they always referred to the grades 
in Standard Mandarin (wunianji and liunianjï ${ }^{11}$, respectively). This could possibly be because their grade level in Chinese complementary school, determined according to the Taiwanese education system, did not match up with their grade level in mainstream Argentine schools.

The three laoshi announced the start of the game. I could not keep track of who won and who lost, given that the field was so chaotic. Despite the fact that there was a soccer game on the same field, there was still a group of boys playing basketball on the far end of the court. The girls talked and played amongst themselves, not paying any attention to the game.

The opportunity to listen in on playground conversations was extremely valuable to this study, as I was able to observe the students' language use when they are not under pressure from authority figures to speak a certain way. Furthermore, because the playground and the school are exclusively Chinese spaces, it can be assumed that everyone is bilingual to some degree in a Chinese variety and in Spanish. That the students generally spoke only in Spanish to each other when in an exclusively co-ethnic space without interference from authority figures reveals quite a bit about their language attitudes and the state of the heritage language among Argentine-born Chinese.

\section{CLASSROOM OBSERVATIONS}

I began my classroom observations the next week. Mauricio took me to a first-grade classroom on the second floor and explained to the teacher why I was there. The teacher approved of my presence in the classroom and invited me to sit in the only available seat in the classroom, a seat in the back row next to a particularly unruly boy named Rubén. (See Appendix 1, Figure 3 for a map of the classroom.)

The teacher, Mrs. Lin, was a middle-aged mother of two who switched to teaching Chinese after selling off her business 14 years ago. She had an assistant, Mr. Chang, a young 
man in his 20s who had emigrated from Taiwan at a young age and had graduated from Academia Hsin-Yi. While Mrs. Lin's Spanish was very limited, Mr. Chang was fluent in both languages, meaning that he served as a cultural mediator between Mrs. Lin and the Argentineborn, Spanish-dominant students.

Mrs. Lin stood in the front of the classroom, by the whiteboard and a computer monitor. She would have a microphone, which was necessary because the class tended to be fairly loud. She also carried a thin bamboo rod that she would rap on students' desks if they were being especially rowdy. While Mrs. Lin gave the lesson, Mr. Chang would circulate around the room, disciplining students in a mix of Spanish and Standard Mandarin.

The first time that I visited the classroom, I was shocked at how rowdy the students were. They were talking loudly amongst themselves (mostly in Spanish), drawing on their textbooks, and getting out of their seats at every opportunity. Upon further reflection, this rowdiness should not have surprised me, as my classmates and I were just as misbehaved in our time in Chinese complementary school in California.

Some of the students gave me curious looks, but I was apparently not interesting enough to grab their attention for more than a second. Only after I began talking to them (in Spanish) did they begin to open up to me. The children were very curious as to why I was there, and asked me many questions. Although I began all of my inquiries in Spanish, they spoke to me almost exclusively in Standard Mandarin, perhaps because Mauricio introduced me as a teacher (and thus an authority figure to whom one should speak Standard Mandarin).

On most visits, I came during the time when Mrs. Lin was introducing new characters to the class. She would pronounce the character, explain the meaning by giving examples of words that contain that character, and then run a program that showed the stroke order in which the character should be written. She would also demonstrate on the board. After all the characters 
have been explained, the students would write the characters several times in their notebooks. Occasionally, they would copy down a sentence that she would write on the whiteboard.

During my visits, I would sit in the back next to Rubén and observe as Mrs. Lin lectured. After the lecture, when the students were supposed to be completing their assignments, I would try to converse with Rubén. Rubén was very talkative, although I did not understand very much of what he said, as he spoke mostly in mumbled Standard Mandarin. I would ask him to explain the words in his assignment, or to tell me stories based on his drawings. I generally spoke to him in Spanish, although, perhaps because he saw me as an authority figure, he almost invariably replied in Standard Mandarin unless I asked him to speak to me in Spanish. This choice of language did not necessarily mean that he was dominant in Standard Mandarin, as he would speak in Spanish to his classmates.

\section{INTERVIEWS}

In addition to participant observation in Mrs. Lin's classroom, I also conducted semistructured interviews ${ }^{12}$ with Mrs. Lin and Mr. Chang, as well as with Pan Wei-Chih, a recent immigrant from Taiwan who teaches Chinese language classes for Argentines of non-Chinese heritage on the third floor of Academia Hsin-Yi. Although I was not able to conduct interviews with second-generation Chinese-Argentines, which would have been extremely useful for this thesis, my interviews with these three subjects gave me significant insights into the Chinese community in Argentina and its collective orientations towards language.

Mrs. Lin

I interviewed Mrs. Lin one day near the end of my stay in Buenos Aires when she had a 
short break between classes. The interview was conducted mostly in Standard Mandarin, with a short portion near the end in Spanish in order to assess her Spanish proficiency and gather a short recording for phonetic analysis in a course I was taking at the time.

Mrs. Lin was born in Taiwan and has lived in Argentina for 27 years. Aside from tutoring elementary students, she had no teaching experience or formal training before starting at Academia Hsin-Yi. However, the principal of the Academia convinced her to teach and taught her some basic classroom skills; in addition, he told her that she should incorporate what she had learned about children from being a mother of two. She taught 13 years of kindergarten in the school before switching to first grade this year.

When she began to teach at the school, most of her students were children of Taiwanese immigrants, and came into the school already speaking Standard Mandarin because they spoke the language at home with their parents ${ }^{13}$. Now, with the demographic shift that is happening in the community, the majority of her students are children of Mainlanders, who speak their parents' native vernaculars at home, or third-generation Taiwanese, who speak Spanish at home. Mrs. Lin finds teaching the former group to be challenging because they speak Standard Mandarin with "funny pronunciations;" on the other hand, teaching the latter group is "like teaching Chinese to foreigners" because they have no Chinese language background.

She asks that the parents of her students speak to them in Standard Mandarin at home, but to no avail. She makes this recommendation based on her own experience-she regrets speaking with her children in Taiwanese, because when they started at the school, they had trouble learning Standard Mandarin. She argues that the Mainland parents should not be speaking to their children in their local variety of Chinese because they can pick it up very easily: “Take them back to their hometowns-within a month they'll be speaking it perfectly."

She claims that none of her students spoke or even understood Standard Mandarin 
before coming into the school. Now, however, she is proud to say they are conversing fluently, though they still prefer to use Spanish in most circumstances. She says that most students who graduate from the Academia speak Standard Mandarin well and are literate in written Chinese; those Chinese-Argentines who do not attend Chinese complementary schools may speak Standard Mandarin fairly well, but are generally illiterate.

Mrs. Lin says that one of the challenges of teaching in the school is that while they use the same textbooks and curriculum as language arts classes in Taiwanese schools, they must teach a week's worth of material in one day. At times, the textbooks are not appropriate for use in Argentina, as they discuss topics particular to Taiwanese society. Most of the students do not have opportunities to go to Taiwan or the Mainland; while their parents may go back often for business reasons, the prohibitive cost of plane tickets make family vacations to the homeland very rare.

Mrs. Lin's Spanish is very weak, and she admits to this. She says that when she first arrived in Argentina, she was busy running her business and raising her family, and thus had no time for Spanish lessons. Her speech clearly marks her as a non-native speaker, and more specifically as a speaker of Asian origin, as the features of her speech often match a stereotyped “Asian” Spanish. Her pronunciation is strongly influenced by the intonation patterns and phonetic inventories of Taiwanese and Standard Mandarin. Grammatically and morphosyntactically, she has trouble with verb conjugations and subject/adjective agreement in terms of number and gender.

\section{Mr. Chang}

Mr. Chang, who is in his 20s, has worked in Academia Hsin-Yi as Mrs. Lin's assistant teacher for the past three months. During the work week, he works as the manager of a Chinese 
supermarket. I interviewed him during class time, while the students were busy doing independent work. The interview was conducted entirely in Spanish.

He was born in Taiwan and immigrated to Argentina at the age of 6 . He attended the Academia as a child and said that it was "fairly effective" at teaching him to read and write in Chinese. Indeed, he says that he is more proficient in reading and writing Chinese than Spanish, despite having attended Argentine schools for most of his educational career. He says that he is not exceptional, and that many "students who are very dedicated" graduate from the Academia with a good command of the language. However, most students are not so dedicated and only attend the school because their parents forced them to.

He believes that many parents in the Chinese-Argentine community talk with their children in Spanish, even if they are not fluent, so that their children will not have as many problems in school. Although he admits to having some difficulty acquiring Spanish when he first arrived in Argentina, he feels that these parents should be speaking with their children in Chinese, as their children will pick up Spanish "naturally" in the classroom. When parents speak with their children in Spanish, he says, the children begin to speak poor Chinese.

He believes that it is extremely important for Chinese immigrants in Argentina to teach the Chinese language to their children so that they do not forget the culture of their ancestors. Parents should speak with their children in Chinese and convince them that, although they live in Argentina, Chinese is just as important as Spanish. Furthermore, he believes that the students should learn Chinese in the school because they can serve as cultural mediators between their parents and the rest of Argentine society. For example, in his job at the supermarket, he interprets for the owners and the other employees because they do not speak Spanish well.

His says that he comes from a very traditional, conservative Taiwanese family. His parents own a supermarket that they have leased to others (it is not clear whether or not this is 
the supermarket in which he works). Among family members, they speak both "Chinese" (Standard Mandarin) and Taiwanese. Because his family maintains many Chinese customs, he feels that he is perfectly comfortable in both cultures, and that he experienced no culture shock when he returned to Taiwan four years after immigrating to Argentina. He says that Argentina is his "mother country," and that he does not plan on returning to live in Taiwan, although he is willing to consider the possibility.

Mr. Chang seems to exhibit the type of language attitudes that I hypothesized would be most conducive to language maintenance (see Hypothesis 4 in Section III). He feels strongly connected to Chinese culture (an integrative orientation, using Gardner and Lambert's [1972] terms) and also sees the Chinese language an economic asset (an instrumental orientation). Furthermore, he is very proud of his connection to Chinese culture and proficiency in Chinese language, and sees them as essential for maintaining traditional Taiwanese family values (an important personal goal). The fact that he spends his Saturdays teaching Standard Mandarin to the youth of the community clearly demonstrates the value that he places on his heritage culture and language.

It is also important to note that as a member of the 1.5 generation who has lived in Argentina for most of his life, Mr. Chang is the interviewee whose language attitudes would closest match those of the second generation. According to Fishman's model of language shift, the second generation is the crucial generation whose language attitudes essentially determine whether or not the heritage language is maintained in subsequent generations.

\section{Pan Wei-Chih}

Pan Wei-Chih is a 35-year-old Chinese language teacher who has lived in Argentina for two years. I met him in the lobby of Academia Hsin-Yi. While we were in Argentina, we spoke 
primarily in English, as his Spanish was not as strong. He majored in English at a prestigious Taiwanese university and worked as an English-Chinese translator in Taiwan before moving to Argentina. Upon arriving in Argentina, he started taking Spanish as a second language classes at the Universidad de Buenos Aires, and has already completed their highest levels of coursework.

His parents are benshengren from the south of Taiwan, and thus they spoke Taiwanese at home. However, because he was born and raised in Taipei, where Standard Mandarin is more commonly spoken, and was educated during the era when students were punished for speaking in Taiwanese, Standard Mandarin became his primary language. When I asked him to list the languages he spoke, he listed "Chinese," English, and Spanish. I then asked him if he spoke Taiwanese, and he said, “Oh, yes. But only as a dialect.”

After visiting Argentina several years ago and falling in love with the country, he moved to Buenos Aires with the intention of teaching Chinese for a living. He shuttles between jobs at three different language schools, and also gives private lessons. He says that most of his students are learning Chinese because they believe that it will be useful for their careers (they think that "Chinese is the language of the future"), or because they are personally interested in Chinese culture.

He notes that he is one of the few Taiwanese to arrive in Argentina in recent years. When he was looking for work soon after arriving in the country, many Taiwanese immigrants did not understand why he was choosing to settle down in Buenos Aires when his countrymen were either returning to Taiwan or moving on to third countries in the aftermath of the Argentine economic crisis of 2001.

At the time of the interview, he had not returned to Taiwan since moving to Argentina. He had a plane ticket to go back in January to visit his elderly parents. He was considering moving back to Taiwan permanently, and knew that he would go back permanently one day. 
One of his major problems in Argentina is that his work in Buenos Aires did not provide him with the job security that he wanted. "I never know how much money I'll have at the end of the month," he said, adding that, in Taiwan, a job teaching Chinese to foreigners would pay much more. Furthermore, teachers are much more respected in Taiwanese culture than in Argentine culture. However, despite these struggles, he was still intending to stay in Argentina for a little bit longer.

He has some Argentine friends, though the majority of his friends are "all foreigners here": Taiwanese, Mainlanders, Americans, and Europeans. He lives in the middle-class Montserrat neighborhood, a historic district close to the seat of the federal government, and commutes an hour by bus to his jobs in Chinatown. He gets along well with all of his neighbors, who are mostly Argentine or Uruguayan art teachers and antique vendors. He also has one neighbor who emigrated from Mainland China; he does not talk with her often.

He is very happy with his current living situation. He says that he gets along well with all of his neighbors, and is very proud of the history of the Montserrat area, one of the oldest neighborhoods in Buenos Aires. The only major problem that he has in his neighborhood is that it borders rougher parts of the city and can be unsafe at night. Often, he will run into groups of cartoneros who will yell “iChino! iChinito!” (“Chinaman! Little Chinaman!”) at him.

A few months after the interview, we had both gone to Taipei, he to visit his family and friends and I to study Chinese. I met up with him several times, and he showed me around his old haunts as a university student. After about six months in Taiwan, he decided to return to teaching Chinese in Buenos Aires.

\footnotetext{
1 牌樓

2 "La comunidad china en Argentina dona con afecto este Arco en ocasión del Bicentenario de la Revolución de Mayo a la bella Ciudad de Buenos Aires y al gran pueblo argentino en agradecimiento por la generosidad y amor brindados a los inmigrantes chinos con el deseo de que la amistad chino-argentina
} 
perdure de generación en generación."

3 "Parece espantoso. ¿Porqué?? Porque este le da mucho más este... digamos poder, o orgullo a los chinos.”

4 "Es indignante que ciudadanos de otro país puedan venir, así como así, y poner una arcada en el comienzo de una calle."

5 “Quién mató este árbol?” These magazines are known in Chinese as 世界周刊, 新大陸新聞周刊, and 新阿根廷周刊, respectively.

$7 \quad$ When I asked Mauricio as to why the students are not divided by language level instead, he gave a very vague answer, saying that students in the same grade should have roughly equivalent language skills. 國字

Code-switching refers to "the juxtaposition within the same speech exchange of passages of speech belonging to two different grammatical systems or subsystems" (Gumperz 1982: 59).

11 五年級 and 六年級

12 See Appendix II for the rubric used to guide these interviews.

13 Whether or not they also spoke Taiwanese at home is unclear. 


\section{Analysis}

This study sought to draw conclusions about the language attitudes of the Chinese-Argentine community through ethnographic methods. Participant observation in the complementary school classroom allowed me to observe the cultural practices and language use patterns of both students and teachers, while semi-structured interviews with teachers and community members gave me insights into the attitudes of those in the community who seek to keep the language alive.

This section is divided into three parts. In the first part, I will analyze examples from my observations and interviews. In the second part, I will respond to the hypotheses outlined in section 4. In third part, I will discuss possible directions for further research into the Chinese community in Buenos Aires and the phenomenon of heritage language loss in Argentina.

\section{PART 1 - ANALYSIS OF OBSERVATIONS AND INTERVIEWS}

Language choice and code-switching

The students generally spoke Standard Mandarin with the teachers, although they also spoke some Spanish to Mr. Chang. Among classmates, the language used varied. When they had a small audience of one or two classmates, they would speak in Spanish, but if they were making a commentary to the entire class, they would speak in Standard Mandarin. (This is perhaps the result of the teachers encouraging them to speak Standard Mandarin in the classroom.) The only times when students would make public comments in Spanish was when they whined, "iNo entiendo!" to signal to each other that they did not understand what the teacher was saying. Occasionally, they would also mix Spanish words into their Standard Mandarin. However, the 
Spanish words that they mix in, such as acento ${ }^{1}$, suggest that they are words used exclusively in the context of Chinese complementary school. For example:

STUDENT: Laoshi, "ke" meiyou acento. ${ }^{2}$ (Teacher, you forgot to put the tone mark on the word "ke.")

The students may be using these Spanish words in their Standard Mandarin because Mrs. Lin uses them. Mrs. Lin would speak almost exclusively in Standard Mandarin, but would use Spanish metalinguistic terms, e.g. sinónimo (synonym), antónimo (antonym), and verbo (verb). On occasion she would also use Spanish to emphasize a point or to define a word. For example:

MRS. LIN: Dizhi shi ni de domicilio.3 (Dizhi means your address.)

Another instance in which I observed Mrs. Lin using Spanish was when the students asked her about a word in the text that they did not understand. As the textbooks that the school used were designed for use in Taiwanese schools, many of the stories and some of the vocabulary was very specific to life in Taiwan, and the students had some difficulty relating to the text. In this particular instance, the students were confused about the word lizit, or Asian pear. While very common in Taiwan and other parts of East Asia, Asian pears are relatively unknown in Argentina, and it is possible that many of the students have never seen or eaten one. After some discussion with Mr. Chang, Mrs. Lin told the students the following:

MRS. LIN: Lizi shi yi zhong pera.5 (Lizi is a type of pear.) 


\section{Maintenance of Chinese culture in the school}

The Academia makes a conscious effort to promote and preserve traditional Chinese culture in the school. This is most apparent in the ways in which students and teachers interact. As Pan Wei-Chih said, teachers in Taiwan receive much more respect from their students than teachers in Argentina. This respect often manifests itself in the social distance that students maintain from their teachers, as well as in more obvious signs of respect. When the teacher enters the room, students must stand up until the teacher permits them to sit. Before the students leave the classroom, they bow to the teacher.

Maintaining this social distance can be difficult for Mr. Chang and the other young teachers at the school. Students may feel that there is no need to address these teachers as elders, as they are close to the students in age and often speak with them in Spanish, which is not the language of authority in the school. One time, a student asked Mr. Chang for his given name, to which he quickly responded, "That is not an appropriate question to ask your elder."

As a participant observer, I had intended to blend into the class as well as I could, sitting in the back of the room and taking notes quietly. If the students had asked, I would have told them the truth-that I was a student, just like them. However, Mrs. Lin and Mr. Chang insisted that I was a teacher, and thus an authority figure. One day, when I came into the classroom, Mr. Chang instructed Rubén, the student in the back row who I sat next to, to remove his belongings from the unoccupied desk so that "the new teacher who just came in" could have a seat. The fact that the teachers told the students that I was also a teacher could possibly explain why the students insisted on speaking Standard Mandarin to me, despite the fact that I always started off conversations with them in Spanish. While it appeared that almost all of them were dominant speakers of Spanish, the rules of the school were that students should speak only Standard 
Mandarin to teachers, and thus they almost invariably spoke with me in Standard Mandarin.

The school's insistence on the maintenance of traditional Chinese culture has many potential implications. This may be an attempt by the school to maintain the cultural boundaries between majority and minority cultures that Fishman argues is requisite for cultural and linguistic maintenance. By having a very different code of conduct from mainstream Argentine schools, the Academia is sending a clear message about the cultural distance between Chinese and Argentines.

Another possible implication of the maintenance of Chinese cultural norms in the school is that it could help guide the students' acculturation into Argentine society by explicitly teaching and enforcing Chinese culture. Using Portes and Rumbaut's (2001: 77) terms, teaching Chinese language and culture is a way of inserting children into the ethnic community and reinforcing the community's cultural values. Reinforcing cultural values has the effect of reducing intergenerational conflict, which often happens when the children are more assimilated than their parents (the so-called "dissonant acculturation" pattern). Thus, while the children are assimilating into Argentine culture, their parents' Chinese values are also being reinforced, reducing or avoiding the intergenerational conflict that may have arisen. Because the parents are often isolated from Argentine society and know very little Spanish, the children are accommodating more to their parents' needs than vice versa. Incidentally, Portes and Rumbaut's types of assimilation do not account for this possibility, in which children are acculturating to local society while maintaining their parents' culture, and the parents are not acculturating at all to local society.

The maintenance of Chinese culture in the school could also be a direct response to the phenomenon of return migration. Many earlier Taiwanese immigrants have returned to Taiwan or moved on to third countries, bringing their Argentine-born children with them. Upon return 
to Taiwan, school-aged children would have to adapt to Taiwanese school norms; because the Academia maintains these norms, these students would have little trouble adjusting to their new school situation.

\section{Oppositional attitudes towards complementary schooling}

In my interview with Mr. Chang, he told me that many students only attended Chinese complementary school because their parents forced them to do it. Thus, it is unsurprising that many students have oppositional attitudes towards the school. ${ }^{6}$ The students' rowdy behavior in the classroom contrasts sharply with the stereotype of Chinese students in mainstream Argentine schools as perfect students (Moure 2009). This behavior suggests many possible explanations. They might view the school as less legitimate than mainstream Argentine schools, or have trouble accommodating a different learning and teaching style, or be bored with the material. This sort of oppositional attitudes towards complementary schooling has been documented in the United States, and has been attributed to a number of possible factors, such as lack of teacher training and differences in teaching style (see Section V).

Some of these problems are also evident at Academia Hsin-Yi. Neither Mrs. Lin nor Mr. Chang had any experience with teaching or education in pedagogical methods before starting at the school. Mrs. Lin was told by the principal to use her experience raising children to help her manage the classroom. While Mr. Chang is very familiar with Argentine pedagogical practices, having been educated in Argentina, Mrs. Lin, who does most of the teaching, presumably is not as familiar. Her emphasis on repetition, recitation, and rote memorization would be familiar to Taiwanese students, but perhaps slightly alienating to students educated in Argentina, where there may be less emphasis on memorization in the classroom.

Another reason why students may hold oppositional attitudes towards the school is 
because the course material may not be relevant to their lives. The school imports textbooks used in language arts classes in Taiwan instead of books written expressly for use in overseas Chinese complementary schools. While the material is theoretically appropriate for the students' grade levels, the content may seem foreign to many of the students. At times, the text uses examples (such as the Asian pear example) that the students do not understand because they are very specific to life in Taiwan. At higher grade levels, I could imagine that the texts would involve even more complex topics, perhaps using stories from Chinese history or modern Taiwanese politics. While students in Taiwan benefit from being surrounded by Chinese culture constantly and taking courses in Chinese history and civics, students using the same textbooks in Argentina may struggle to understand the cultural and historical references. When students are presented with material that they do not understand, or that is not relevant to their lived experiences and does not build upon concepts that they learned in other classes and contexts, they may react negatively and develop oppositional attitudes.

In an attempt to counter these oppositional attitudes, Mrs. Lin constantly stresses the importance of studying Chinese. Once, she told the class, "Because we have Spanish school, we don't have much time to learn Chinese. That's why it's important to read the textbook three times a day." However, considering the students' difficulty with remembering tones of words and with writing simple characters, it is unlikely that the students are "reading the textbook three times a day" or even having their Chinese abilities reinforced outside of the classroom at all. Since Chinese immigrants in Buenos Aires live across the city, it is not unlikely that these students may find themselves to be the only Chinese students in their mainstream schools, and thus have no opportunity to practice the language with peers that they interact with on a daily basis. 
Teachers' thoughts on complementary schooling and its success rate

Mrs. Lin and Mr. Chang both believed that complementary schools such as Academia Hsin-Yi play an important role in the community. Mr. Chang stated directly (and Mrs. Lin indicated indirectly) that it is essential for the youth of the Chinese-Argentine community to speak and learn Chinese (meaning Standard Mandarin). Both seemed to be very positive about the success that Academia Hsin-Yi and other complementary schools in Buenos Aires have in teaching Standard Mandarin to the youth of the Chinese-Argentine community. However, Mr. Chang did point out that many students only attend these schools because their parents forced them to, and that these students tended not to have as much success as he did.

It is possible that Mrs. Lin and Mr. Chang tried to paint a rosier picture of the school when talking to me, an outside interviewer. Considering that Mrs. Ma, the director of educational affairs, told me quite bluntly that she did not understand the point of my study because "everyone knows that the students all speak Spanish outside of class, anyway," the general consensus among teachers and administrators at the school may be that it is not as successful as it could be at encouraging language maintenance.

Non-standard varieties of Chinese

All three informants interviewed used the term "Chinese language" (chino in Spanish or zhongwen 7 in Standard Mandarin) to mean "Standard Mandarin." Taiwanese, the other variety of Chinese that all of the informants mentioned, was distinct from chino or zhongwen. Thus, implicitly, only Standard Mandarin could be linked to a transnational or transregional "Chinese" identity; Taiwanese and other non-standard vernaculars are linked to a specific local identity. Mrs. Lin lamented the fact that many Mainland immigrant parents spoke to their 
children in their local vernacular, and regretted speaking to her children in Taiwanese instead of Standard Mandarin. By saying that they would learn it quickly if sent back to their hometowns for a short stay, indicated that she viewed these vernaculars as less prestigious, less complex, and less worthy of acquisition and maintenance. In her study of Chinese complementary schools in Spain, Nieto (2007: 119) found that teachers at complementary schools there had similar attitudes towards non-standard vernaculars:

"Chinese school teachers often expressed their discontent at the fact that the children arrived at the school knowing how to speak the dialect of their parents, but not the common language (Putonghua), as if that implied the lack of the cultural capital necessary to be Chinese." (Nieto 2007: 119, emphasis in the original)

Thus, according to this logic, knowledge of Standard Mandarin is essential for being Chinese in the diaspora. That the teachers are so disparaging of local vernaculars undoubtedly contributes to the decline in their use among ethnic Chinese youth growing up in Argentina.

\section{PART 2 - REVISITING THE HYPOTHESES}

Hypothesis 1 : Evidence of heritage language loss

My first hypothesis was that heritage language loss is occurring in the Chinese community in Argentina, and that the conflicting ideas about language that second-generation Chinese-Argentines receive from inside the community and from the rest of Argentine society directly affect the pace of language loss and their efforts towards language maintenance. 
What I observed in the field supports this hypothesis. Heritage language loss is indeed happening in the Chinese-Argentine community. Most of the second- and third-generation Chinese-Argentines that I met spoke Spanish as their dominant language. Mrs. Lin told me that teaching her students was like "teaching Chinese to foreigners," as the majority of the students were second- or third-generation Chinese-Argentines who did not speak Standard Mandarin at home. Most of the second-generation students were children of Mainland immigrants who spoke their parents' native vernaculars at home; Mrs. Lin complained that these students had "funny pronunciations" in Standard Mandarin. The third-generation students were generally monolingual speakers of Spanish before they started at the school, as their parents spoke Spanish to them.

The fact that the third-generation students, presumably grandchildren of the earliest Taiwanese immigrants, came into the school speaking only Spanish because their parents spoke to them in Spanish is a clear indicator that the pattern of language loss is following Fishman's model. The second generation, more dominant in Spanish than in Chinese, speaks to the third generation in Spanish, meaning that Chinese does not get passed down to subsequent generations. Thus, it is unsurprising that Mrs. Lin's request that parents speak to their children in Standard Mandarin is falling on deaf ears; some parents may speak Standard Mandarin haltingly, if at all.

The fact that the students who were children of Mainland immigrants came into the school speaking their parents' native vernaculars indicates that these parents are most likely speaking to them in that variety. However, it does not necessarily mean that these local vernaculars are going to survive. I did not observe a single instance in which a student was speaking with another student in a language other than Spanish or Standard Mandarin.

There are several possible explanations as to why this is happening. Because Mainland 
immigrants to Argentina come from many different regions of China, few classmates speak the same variety of Chinese at home, and thus the students use Spanish and Standard Mandarin as lingua francas. Another possibility is that the teachers and the school are strongly discouraging the use of non-Standard Mandarin varieties of Chinese, although I did not see any evidence of this. Considering that Mrs. Lin would have been educated in Taiwan during the period when students were punished for speaking non-Standard Mandarin varieties, and her own statements about the students' "funny pronunciations" that need to be corrected, I would not be surprised if she had discouraged the students from speaking their parents' vernaculars. However, she does not discourage them from speaking Spanish, which they use more often than Standard Mandarin in the classroom. This may be a tacit acknowledgment of the high status of Spanish in Argentine society.

\section{Hypothesis 2: Applying the Fishman model}

Because third-generation Chinese-Argentine students are still enrolled in complementary schools and acquiring Standard Mandarin there, the heritage language loss happening in the Chinese community in Argentina does not match up exactly with the classical Fishman model. While third-generation children are generally being raised monolingually in Spanish, they are still acquiring Standard Mandarin as a second language in complementary schools. Spanish is still their dominant language, and they only speak the language in certain contexts, such as when they are in Chinatown or interacting with relatives and family friends. Non-standard varieties of Chinese seem to be lost entirely by the second generation; the second generation may speak these varieties at home, but because these varieties are generally not reinforced in any other contexts, they are gradually lost. This is also happening with Taiwanese, despite the fact that it is commonly spoken among Taiwanese immigrants, who 
make up a significant portion of the community. Among Argentine-born Chinese, it may be the case that, because of the relative prestige of these languages and the frequency that these languages are used, Spanish supersedes any variety of Chinese as the dominant language, and Standard Mandarin supersedes non-standard vernaculars.

Because it is their dominant language, Argentine-born Chinese use Spanish almost exclusively, even among their bilingual Chinese-Argentine peers. In my observations on the playground and in the hallways of the school, almost all students spoke to each other in Spanish. In the classroom, they would speak Standard Mandarin to Mrs. Lin and when making a public commentary to the class; among friends and to Mr. Chang, they would speak Spanish.

This pattern of language use does not bode well for the maintenance of Chinese language in the community. Fishman argued that because of economic, political, and educational dependency on the dominant group, minority groups are unable to control their own cultural boundaries, leading to cultural assimilation and language loss. This dependence on the dominant group gives the language of that group higher prestige and higher utility than the minority language, resulting in members of the minority group acquiring the majority language and "displacively [using] it with one another, on the 'inside', for advantages which also obtain even within the weakened and transculturating minority community itself' (Fishman 1991: 357, emphasis in the original).

The Chinese-Argentines that I observed were clearly using Spanish in place of Chinese for intragroup communication, but what advantages might that bring? As their physical features often cause their "Argentineness" to be called into question, one of the possible advantages of speaking Spanish within the community is to forge a collective identity as Argentines. In Anderson's (1991: 6) terms, Chinese-Argentines may be using the Spanish language as a tool in the act of "imagining" their community; not only does their common dominant language 
connect individuals in the community to each other, but also links them to the majority of Argentine society and sets them apart from their immigrant forebears, stereotyped as foreign, unscrupulous, and unwilling to integrate.

Even though complementary schools are teaching the language and students of all immigrant generations are still attending, these schools, on their own, are unlikely to be able to stop language shift on their own. Fishman (1991: 371) argues that, "without considerable and repeated societal reinforcement schools cannot successfully teach either first or second languages and, furthermore, where such reinforcement is plentifully available, languages are acquired and retained even if they are not taught in school." He goes on to say that, because the ethnic mother tongue is inextricably tied to personal identity and community relationships, reversing language shift must begin with the family and the community. Schools are "insufficiently undisputed, affect-laden, intimacy- and identity-focused or societally binding for such purposes;" however, by actively fostering positive language attitudes, they can help to develop the family and community conditions necessary for heritage language maintenance (Fishman 1991: 375). Fishman made this argument in reference to mainstream schools with heritage language programs. Because students spend much less time at weekend complementary schools, and these schools are not linked to the authority structure of mainstream schools, it could be argued that complementary schools need to work even harder to promote the ethnic mother tongue.

However, the Chinese complementary schools in Buenos Aires, and Academia Hsin-Yi in particular, have a strategic advantage: they are much more closely tied to the community than mainstream schools. These complementary schools are among the few spaces where ChineseArgentines from across the city come together. Academia Hsin-Yi has an advantage in that it is tied to the church, which is another community space. Because the church and the school are 
run by the community and directly serve the community, it is better poised to foster positive attitudes towards Chinese language and culture than any institution coming from outside.

Even so, it does not appear that the school has been very successful at teaching the heritage language to the majority of students and encouraging students to actively speak and maintain it. While there are the occasional success stories, such as Mr. Chang, most students do not fare as well in the school, and some teachers and administrators seem to have given up on their mission.

Hypothesis 3: Can Standard Mandarin be the exception to the language loss rule?

My third hypothesis was that because subsequent generations of Chinese-Argentines are learning Standard Mandarin, a language of high prestige, Standard Mandarin may survive as a heritage language even if non-standard varieties do not. According to Mrs. Lin, many Taiwanese immigrants speak to their children in Standard Mandarin, which is the language that is reinforced in complementary schools. Thus, at least for this subgroup, home language practices reinforce the complementary school curriculum, and vice versa. This is significantly better than for students who speak Spanish or other varieties of Chinese at home, for whom the complementary school is, in effect, teaching a foreign language that is not reinforced elsewhere. However, even children of Taiwanese immigrants who spoke Standard Mandarin at home and acquired Chinese literacy through Standard Mandarin in complementary schools choose to raise their children monolingually in Spanish. Clearly, neither Taiwanese nor Standard Mandarin is being passed down to subsequent generations, refuting my hypothesis.

Even though Standard Mandarin may not be the exception to the language loss rule, it may still play some role in the community. Because both the Chinese-Argentine community and wider sectors of Argentine society see Standard Mandarin as a tool for economic success, and 
because this standard variety is tied to a sense of Chinese ethnic identity (c.f. Nieto 2007), Standard Mandarin may continue to enjoy a degree of high prestige among Chinese-Argentines, much like it does among ethnic Chinese in Singapore and Malaysia, or like English among Anglo-Argentines.

Hypothesis 4: Attitudes towards complementary schooling and motivations for Chineselanguage acquisition

My fourth hypothesis, based on Gardner \& Lambert and Cooper \& Fishman’s studies, was that students in complementary schools who feel strongly connected to Chinese culture and see proficiency in Chinese as a cultural or economic asset, and additionally see their connection to Chinese culture and proficiency in Chinese language as serving important personal goals are the students who will be most successful at maintaining the heritage language.

While I was not able to investigate this hypothesis directly, my interview with Mr. Chang indirectly supports this conjecture. Mr. Chang, who left Taiwan for Argentina at a young age, successfully maintained his command of Chinese with the help of Saturday classes at the Academia. He claims that he is more proficient with written Chinese than with written Spanish, despite having attended Argentine schools for almost all of his life. (However, it may be important to point out that he did begin his schooling in Taiwan and acquired Spanish at a more advanced age than most Argentine-born Chinese.)

Based on my hypothesis, it is unsurprising that Mr. Chang feels a strong connection to Chinese culture, and that he sees the Chinese language as essential for meeting his career and personal goals. That he chooses to spend his Saturdays teaching Standard Mandarin to young children is, by itself, a strong indicator of the value that he places on the language and the connection that he feels with the rest of the Chinese-Argentine community. It is clear that 
maintenance of Chinese language and culture is an issue of personal importance to him; he believes that Chinese-Argentines should not abandon the language and culture of their ancestors, though Argentina may be their "mother country.” Aside from being of personal importance, the Chinese language also plays an important role in his day job as a supermarket manager. There, he serves as an interpreter and cultural mediator between the Chinese supermarket owners and the Argentine employees. He feels that facilitating communication between the two groups is an important aspect of his job, and a function that Argentine-born Chinese are uniquely poised to serve.

\section{PART 3 - DIRECTIONS FOR FURTHER RESEARCH}

This thesis is exploratory in nature, and by no means aims to be a thorough investigation into the Chinese community in Buenos Aires or the phenomenon of heritage language loss in new immigrant communities in Argentina. A precursory study like this one naturally leaves many questions unanswered and opens up many more questions that were not considered at the start. The following are some remaining questions that may prove useful to consider in further research on these topics.

What role do mainstream Argentine schools play in heritage language loss and maintenance?

Do the language policies of Argentine schools encourage bilingualism for linguistic minorities, or does it discourage it? If there are explicitly defined language policies in place, do they conflict with the general school environment?

I was only able to observe the students in Mrs. Lin's class on Saturdays, when they are 
surrounded by co-ethnics in an environment that actively encourages heritage language maintenance. However, they are only in this environment one day a week, and spend most of their waking hours in mainstream Argentine schools where they are taught in Spanish and face considerable pressure to assimilate and "fit in."

In the United States, school language policy is one of the primary factors affecting heritage language loss and maintenance. Most American schools employ so-called "subtractive" language policies, in which teachers aim to replace students' home languages with the majority language (Corson 1999: 175). Some schools may do this by teaching in English only, with no heritage language support for students who do not speak English fluently. Other schools may use the heritage language as a tool in the initial years of schooling to teach students English as quickly as possible; after the students are deemed to have mastered English well enough for the mainstream, monolingual classroom, they are transitioned into these classrooms and are not provided with heritage language support (Corson 1999: 172). Zhou (1997: 88) notes that both of these doctrines treat the heritage language "as the source of a hindrance rather than as an asset."

Argentine school language policy was intentionally subtractive during the "great wave" of European immigration, when local elites used education as a tool to create a cohesive national identity that included and assimilated descendants of immigrants from all over Europe. Has this policy changed over time to handle the smaller flows of immigrants coming in from Asia in recent decades? From the conversations that I had with some members of the ChineseArgentine community who grew up in Argentina and attended Argentine schools, it appears that language support is very limited, and many students from Chinese-speaking families have a difficult time acquiring Spanish initially. Furthermore, because Chinese immigrants live throughout the city and their children presumably attend schools in the neighborhood, there is 
no single concentration of Chinese-Argentine students, which would make extra language support for this group difficult to provide.

If heritage language support is limited or not available, Argentine school policies would most likely be considered subtractive, if not intentionally so. While mainstream Argentine schools may not be intentionally trying to "wipe out" minority languages, by putting language minority students in monolingual classrooms with no heritage language support-an action which generally results in language loss-they are sending a strong message about language use in Argentine society. Schooling is one of the first experiences that children have with authority outside the home. Excluding the home language from this authority structure reinforces students' perceptions that the language of power in society is the language of the dominant majority, and not the language that they speak at home. They will acquire the language of the dominant majority in the classroom, but without the opportunity to develop their heritage language skills within this authoritative structure, their skills may begin to decline.

Kenner (2004: 153) argues that if there are no resources to provide heritage language support, a school could implement a policy supportive of heritage language maintenance by encouraging students to develop their heritage language abilities outside of the mainstream school system, and by encouraging students to value their heritage languages as much as they value the dominant language. This is where complementary schools come into play. Complementary schools allow students the opportunity to develop their heritage language skills outside of the mainstream classroom. However, students may not see complementary schools as authoritative or worth their while if mainstream schools do not support these schools in their mission by encouraging students to attend and/or give credit for good performance in these schools. Wang (1996: 65) argues that recognition and credit from mainstream schools may help complementary schools in the United States teach the heritage language more effectively and 
partially solve the problem of complementary school dropouts. Would the same be true in Argentina?

How do Argentines feel about bilingualism, and how does this affect heritage language loss?

In Section 3, I posed a question about the impact of national orientations towards foreign languages on heritage language loss. While I have observed that lessons in English and Chinese appear to be in high demand, the limited scope of this study has precluded me from probing deeper into Argentina's national attitudes towards foreign language acquisition and bilingualism. More importantly, I have not been able to assess Argentines' opinions on bilingualism for immigrant minorities. The difference between bilingualism for the elite and bilingualism for oppressed minorities is very distinct in the United States. For immigrants, children of immigrants, and native peoples, bilingualism is seen as a hindrance to successful adaptation to mainstream American society. However, for the children of the native-born American sociocultural elite, bilingualism is seen as a highly valued asset (Wortham, Murillo, and Hamann 2002).

How does the difference in political, economic, and cultural power between the United States and Argentina come into play?

One important factor that determines national orientations towards bilingualism and foreign language acquisition is a nation's political, economic, and cultural clout. The United States, being the world's dominant political and economic player and also a major exporter of both high culture and popular culture, has the clout to make its language the preeminent world language, the sine qua non of engagement with other nations and cultures. Argentina, on the 
other hand, has been in a state of slow economic decline since after World War II, and has been eclipsed in its political and cultural prowess by other major regional players, most notably Brazil. Thus, it is unsurprising that Americans are loath to learn foreign languages, while Argentines have an insatiable demand for language courses-for Argentines, proficiency in a foreign language is a matter of survival and a means for participating in global political and economic affairs outside of Spanish America.

Pan Wei-Chih said that many of his Argentine students are learning Chinese because they believe that it is the "language of the future." What does this attitude towards the Chinese language mean for heritage language maintenance in the Chinese-Argentine community? Do Chinese-Argentines see the Chinese language as an important tool and a means of social mobility? Or do the pressures to assimilate cancel out these positive attitudes towards the language?

The group whose opinion may best reflect the way the community handles these conflicting attitudes is adolescents and university students, who are in the process of making decisions about their education and job preparation that will determine the path that they take in the future. Are they actively trying to improve their Chinese language ability because of its perceived importance in the global economy? Are there any regrets about language loss, which are common among Chinese-Americans in the same age group? Further interviews with this age group may be able to answer these questions.

How does Academia Hsin-Yi compare to other complementary schools in Buenos Aires, and to complementary schools in other parts of the world?

One of the limitations of this study was that I was only able to observe at one school and interact with the students and staff at that one school. Thus, I have been generalizing about the 
Chinese community in Argentina and about the effectiveness of the complementary schools in Buenos Aires based on a very limited sample. Observations and interviews at one or both of the other schools would have benefitted this thesis immensely by providing a much fuller picture of the language situation in the community.

Comparisons with Chinese communities and complementary schools elsewhere would also have strengthened this thesis. How do complementary schools in Buenos Aires compare to schools in other urban areas of the Spanish-speaking world with relatively new Chinese populations, such as Madrid? How do these schools in new communities compare to schools in more established communities, such as Panama City or Lima? Finally, how do schools in the Spanish-speaking world compare to those in the English-speaking world, given the differences in power between the Spanish and English languages?

1 Accent (mark), here referring to diacritics used to mark tones in the zhuyin fuhao (注音符號; also known in English as Mandarin Phonetic Symbols) syllabary used to teach Mandarin pronunciation in Taiwan.

2 “老師, '課' 没有 acento.”

3 “地址是你的 domicilio.”

4 梨子

5 “梨子是一種 pera.” (Incidentally, Western pears are also known as 梨子 in Chinese.)

$6 \quad$ It is possible that this conclusion may be influenced by the so-called "experimenter's bias.” Because I held oppositional attitudes towards the Chinese complementary school that I attended as a child, I may have expected that the students I observed felt the same way.

7 中文

8 "Las profesoras de los colegios chinos expresaban a menudo su descontento porque las y los niños llegaban a la escuela sabiendo hablar el dialecto de sus padres, pero no la lengua común (el putonghua), como si ello implicara la falta de cierto capital cultural necesario para ser chino." 


\section{Conclusion}

Despite the efforts of complementary schools, heritage language loss is occurring in the Chinese community in Buenos Aires. Faced with strong pressure to assimilate, Argentine-born Chinese are abandoning their home languages for Spanish. While Chinese complementary schools like Academia Hsin-Yi may be encouraging the maintenance of Chinese culture and the development of Chinese language skills, it is unclear how long Chinese culture and language will survive in the community if, as Fishman argues, the Chinese community is unable to manage its own cultural boundaries and is dependent on the rest of Argentine society for survival.

Furthermore, complementary schools are only teaching Standard Mandarin; even if this variety of Chinese survives into subsequent generations, because of the lack of reinforcement outside of the home, non-standard varieties like Taiwanese and Shanghainese will not. If immigration from greater China were to stop, the Chinese-Argentine community may become entirely monolingual in Spanish. Another possibility is that it may become like the Anglo-Argentine community or Chinese communities in Singapore and Malaysia, where the ancestral language (in the case of the Anglo-Argentines) or the standard language of the state controlling the ancestral region (in the case of Chinese in Singapore and Malaysia) becomes a sort of "dummy" language of prestige.

I hope that this study will highlight the need for further study of the Chinese community in Argentina, which is little understood, even within the country. There are already thirdgeneration Argentine-born Chinese in the community, and the arrival of new immigrants from Mainland China means that the Chinese presence in Argentina will continue. Even though they have formed a part of the fabric of Argentine society for many decades now, few scholars have taken a look at the community and how it is structured, how it interacts with other groups, and 
how it is adapting to Argentina's social conditions. More attention from the Argentine and international scholarly communities may help clear up the many misunderstandings of the community, propagated by biased media and stereotyped perceptions.

I also hope that this study will spur more research into how immigrant communities combat the phenomenon of heritage language loss. Complementary schools, like Academia Hsin-Yi, are one method. How do other communities, in other contexts, respond to the rapid cultural shift that happens as their youth assimilate into the mainstream, dominant culture of the receptor country? Fishman would argue that community language programs cannot reverse language shift on their own; in that case, what else can the community do? Understanding how complementary schools and other community-based heritage language maintenance programs work may give us a clearer understanding of the mechanics of language shift, and give us ideas as to how to push back against the tide of language homogenization. 


\section{Works Cited}

Agence France-Presse. "Buenos Aires: cizaña en el barrio chino" [Buenos Aires: Discord in Chinatown]. AFP Videos-Español, 9 Jun 2009. Web. 6 Nov 2010.

Anderson, Benedict. Imagined Communities: Reflections on the Origin and Spread of Nationalism. Revised edition. New York: Verso, 1991. Print.

Artusa, Marina. "Los chinos de acá” [Local Chinese people]. Clarín, 8 May 2005. Web. 6 Nov 2010.

Bilbao, Horacio and María Farber. "En la Argentina ya hay 70 mil chinos que no dejan de trabajar ni en su Año Nuevo" [In Argentina there are 70,00o Chinese who do not stop working, even during their New Year]. Clarín, 25 Jan 2009. Web. 2 Dec 2009.

Chao, Theresa Hsu. “Overview.” A View from Within: A Case Study of Chinese Heritage Community Language Schools in the United States. Ed. Xueying Wang. Washington, D.C.: The National Foreign Language Center, 1996. Print.

Clarín. "El Año del Tigre arrancó con una multitud en el Barrio Chino" [The Year of the Tiger starts off with a crowd in Chinatown]. Clarín, 15 Feb 2009. Web. 6 Nov 2010.

Cooper, Robert L. and Joshua A. Fishman. “A Study of Language Attitudes.” The Spread of English: The Sociology of English as an Additional Language. Eds. Joshua A. Fishman, Robert L. Cooper, and Andrew W. Conrad. Rowley, Massachusetts: Newbury House, 1977. Print.

Corson, David. Language policy in schools: a resource for teachers and administrators. Mahwah, N.J.: Lawrence Earlbaum, 1999. Print.

Cortés Conde, Florencia. Los angloargentinos en Buenos Aires: Lengua, identidad y nación antes y después de Malvinas [The Anglo-Argentines in Buenos Aires: Language, identity 
and nation before and after the Falklands War]. Buenos Aires: Biblos, 2007. Print.

---. The Anglo-Argentine bilingual experience. Diss. University of Texas at Austin, 1993. Ann Arbor: UMI, 2004. Print.

Courtis, Corina. Construcciones de alteridad: Discursos cotidianos sobre la inmigración coreana en Buenos Aires [Constructions of otherness: Everyday discourses about Korean immigration in Buenos Aires]. Buenos Aires: Eudeba, 2000. Print.

Crystal, David. A Dictionary of Language. 2nd ed. Chicago: University of Chicago Press, 2001. Print.

Erbaugh, Mary S. "Southern Chinese dialects as a medium for reconciliation within Greater China." Language in Society 24.1 (1995): 79-94. Print.

Feifel, Karl-Eugen. Language attitudes in Taiwan: A Social Evaluation of Language in Social Change. Taipei: Crane, 1994. Print.

Fishman, Joshua A. Reversing Language Shift: Theoretical and Empirical Foundations of Assistance to Threatened Languages. Clevedon, England: Multilingual Matters, 1991. Print.

---. "The Status and Prospects of Bilingualism in the United States.” The Modern Language Journal 49 (1965): 143-155. Print.

Fontanella de Weinberg, María Beatriz. La asimilación lingüística de los inmigrantes: Mantenimiento y cambio de la lengua en el sudoeste bonaerense [The linguistic assimilation of immigrants: Maintenance and language change in southwestern Buenos Aires Province]. Bahía Blanca, Argentina: Universidad Nacional del Sur, 1979. Print. ---. "Variables que actuaron en el mantenimiento y cambio de lengua" [Variables involved in language maintenance and change]. Lengua e inmigración: Mantenimiento y cambio de lenguas inmigratorias [Language and immigration: Maintenance and change in 
immigrant languages]. Eds. Fontanella de Weinberg, María Beatriz, Mercedes Blanco de Margo, Yolanda Hipperdinger, Elizabeth Rigatuso, Silvia Suardíaz de Antollini, and Ana Virkel de Sandler. Bahía Blanca, Argentina: Universidad Nacional del Sur, 1991. Print.

Gardner, Robert C. and Wallace E. Lambert. Attitudes and Motivation in Second-Language Learning. Rowley, Massachusetts: Newbury House, 1972. Print.

Geertz, Clifford. The Interpretation of Cultures. New York: Basic Books, 1973. Print.

Gilliland, Joshua. "Language Attitudes and Ideologies in Shanghai, China." MA thesis. The Ohio State University, 2006. Print.

Grimson, Alejandro. "Nuevas xenofobias, nuevas políticas étnicas en Argentina" [New xenophobias, new ethnic politics in Argentina]. Instituto Interamericano de Derechos Humanos, n.d. Web. 20 Oct 2010.

Gumperz, John J. Discourse strategies. New York, Cambridge University Press, 1982. Print. Guo, Longsheng. "The Relationship between Putonghua and Chinese Dialects." Language Policy in the People's Republic of China: Theory and Practice Since 1949. Eds. Minglang Zhou and Hongkai Sun. Boston: Kluwer, 2004. Print.

Harrison, K. David. When Languages Die: The Extinction of the World's Languages and the Erosion of Human Knowledge. New York: Oxford University Press, 2007. Print.

Hidalgo, Margarita. "Language Contact, Language Loyalty, and Language Prejudice on the Mexican Border." Language in Society 15.2 (1986): 193-220. Print.

Hong, Weiren [洪惟仁]. Taiwan yuyan weiji [台灣語言危機; Taiwan's language crisis]. Taipei: Qianwei [前衛], 1992. Print.

Ingulsrud, John E., and Kate Allen. Learning to Read in China: Sociolinguistic Perspectives on the Acquisition of Literacy. Lewiston, N.Y: E. Mellen Press, 1999. Print.

Instituto Nacional de Estadística y Censos. "Población extranjera empadronada en el país por 
lugar de nacimiento, según sexo y grupos de edad. Año 2001" [Foreign population registered in the country by place of birth, sex, and age groups. Year 2001]. 2001. Web. 10 Sep 2010.

Kenner, Charmian. Becoming biliterate: Young children learning different writing systems. Stoke on Trent, UK: Trentham Books, 2004. Print.

Lewis, M. Paul, ed. Ethnologue: Languages of the World. 16th ed. Dallas: SIL International. 2009. Web. 30 Nov 2010.

López, David. “Language: Diversity and Assimilation.” Ethnic Los Angeles. Eds. Roger Waldinger and Mehdi Bozorgmehr. New York: Russell Sage, 1996. 139-163. Print. McGowan, Miranda Oshige, and James Lindgren. "Testing the "Model Minority Myth.” Northwestern University Law Review. 100.1 (2006): 331-378. Web. 30 Nov 2010.

Mera, Carolina. "Migración coreana: identidades entre desplazamientos y anclajes" [Korean migration: identities between displacement and anchorage]. Relaciones interculturales: experiencias y representación social de los migrantes [Intercultural relations: migrants' experiences and social representation]. Eds. Néstor Cohen and Carolina Mera. Buenos Airse: Antropofagia, 2005. Print.

Moure, José Luis. Personal interview. 30 Nov 2009.

Nieto, Gladys. La inmigración china en España: una comunidad ligada a su nación [Chinese immigration to Spain: a community linked to its nation]. Madrid: Libros de la Catarata, 2007. Print.

Peng, Yu-Min. "Short-term Professional Development for Teachers." A View from Within: A Case Study of Chinese Heritage Community Language Schools in the United States. Ed. Xueying Wang. Washington, D.C.: The National Foreign Language Center, 1996. Print. Platt, John T. "A Model for Polyglossia and Multilingualism (With Special Reference to 
Singapore and Malaysia)." Language in Society 6.3 (1977): 361-378. Print.

Portes, Alejandro, and Rubén G. Rumbaut. Legacies: the story of the immigrant second generation. New York: Russell Sage, 2001. Print.

Portes, Alejandro, and Richard Schauffler. "Language and the Second Generation: Bilingualism Yesterday and Today.” The New Second Generation, ed. Alejandro Portes. New York: Russell Sage, 1996. 8-29. Print.

Romaine, Suzanne. Bilingualism. New York: Basil Blackwell, 1989. Print.

Russo, Victoria. "Construyen un arco en el Barrio Chino" [Building an arch in Chinatown]. La Nación, 23 May 2009. Web. 6 Nov 2010.

Sandel, Todd L. "Linguistic Capital in Taiwan: The KMT's Mandarin Language Policy and Its Perceived Impact on Language Practices of Bilingual Mandarin and Tai-gi Speakers.” Language in Society 32.4 (2003): 523-551. Print.

Sandel, Todd L., Wen-Yu Chao, and Chung-Hui Liang. "Language Shift and Language Accommodation across Family Generations in Taiwan.” Journal of Multilingual and Multicultural Development 27.2 (2006): 126-147. Print.

Santamaría, Roxana, and Gabriela Itzcovich. "Percepciones y prejuicios hacia inmigrantes coreanos y paraguayos residentes en la Argentina” [Perceptions and prejudices towards Korean and Paraguayan immigrants resident in Argentina]. Relaciones interculturales: experiencias y representación social de los migrantes [Intercultural relations: migrants' experiences and social representation]. Eds. Néstor Cohen and Carolina Mera. Buenos Aires: Antropofagia, 2005. Print.

Sassone, Susana, and Carolina Mera. "Barrios de migrantes en Buenos Aires: Identidad, cultura y cohesión socioterritorial” [Migrant neighborhoods in Buenos Aires: Identity, culture, and socioterritorial cohesion]. Réseau Amérique Latine. 2006. Web. 10 Sept. 2010. 
Spradley, James P. Participant Observation. New York: Holt, Rinehart and Winston, 1980. Print.

University of California, Los Angeles. Heritage language research priorities conference report. Los Angeles: University of California, Los Angeles, 2001. Web. 30 Nov 2010.

Van Deusen-Scholl, Nelleke. “Toward a Definition of Heritage Language: Sociopolitical and Pedagogical Considerations." Journal of Language, Identity \& Education 2.3(2003): 211-230. Print.

Wang, Shu-han Chou. "Improving Chinese Language Schools: Issues and Recommendations.” $A$ View from Within: A Case Study of Chinese Heritage Community Language Schools in the United States. Ed. Xueying Wang. Washington, D.C.: The National Foreign Language Center, 1996. Print.

Watson, Graham. “Make Me Reflexive, but Not Yet: Strategies for Managing Essential Reflexivity in Ethnographic Discourse.” Journal of Anthropological Research 43.1(1987): 29-41. Print.

Wortham, Stanton, Enrique G. Murillo, Jr., and Edmund T. Hamann. "Recent Language Minority Education Policy in Georgia: Appropriation, Assimilation, and Americanization." Education in the New Latino Diaspora: Policy and the Politics of Identity. Eds. Stanton Wortham, Enrique G. Murillo, Jr., and Edmund T. Hamann. Westport, CT: Ablex Publishing. 2002. Web. 2 July 2010.

Yang, Rongjian [楊鎔鑑]. Agenting, Zhili, Wulagui huaqiao gaikuang [阿根廷、智利、烏拉圭華 僑概況; Overview of the situation of Overseas Chinese in Argentina, Chile, and Uruguay]. Taipei: Zhengzhong Shuju [正中書局], 1988. Print.

Zhou, Min. “Growing Up American: The Challenge Confronting Immigrant Children and Children of Immigrants." Annual Review of Sociology 23 (1997): 63-95. Print. 
Zuzek, Cristina. "Identidad y aculturación: el caso de los inmigrantes taiwaneses jóvenes" [Identity and acculturation: the case of young Taiwanese immigrants]. Instituto de Investigación en Ciencias Sociales. Universidad del Salvador, 2004. Web. 10 Sept. 2010. 


\section{Appendix 1 - Figures}

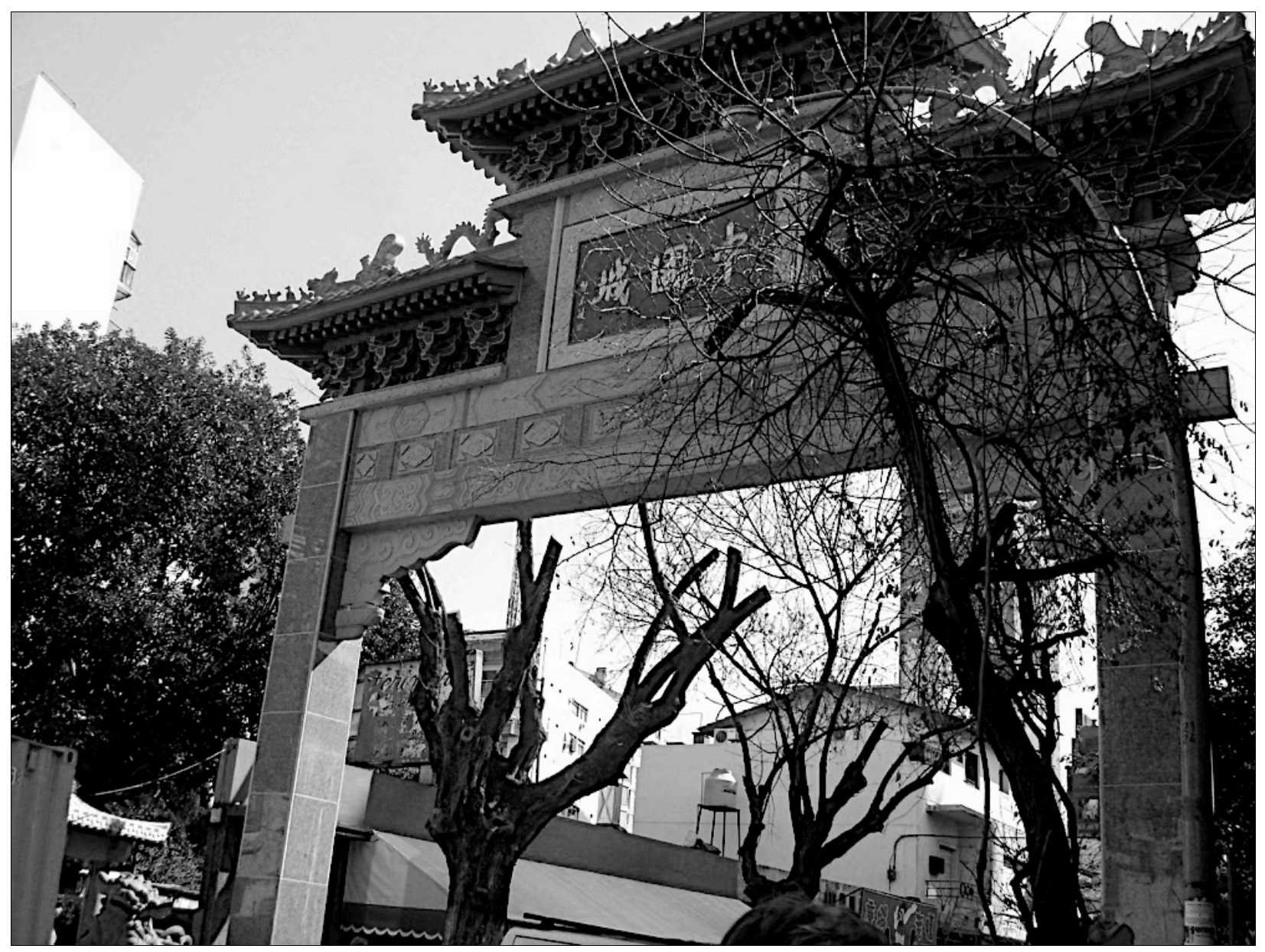

Figure 1 - The pailou at Juramento and Arribeños Streets in Chinatown. 


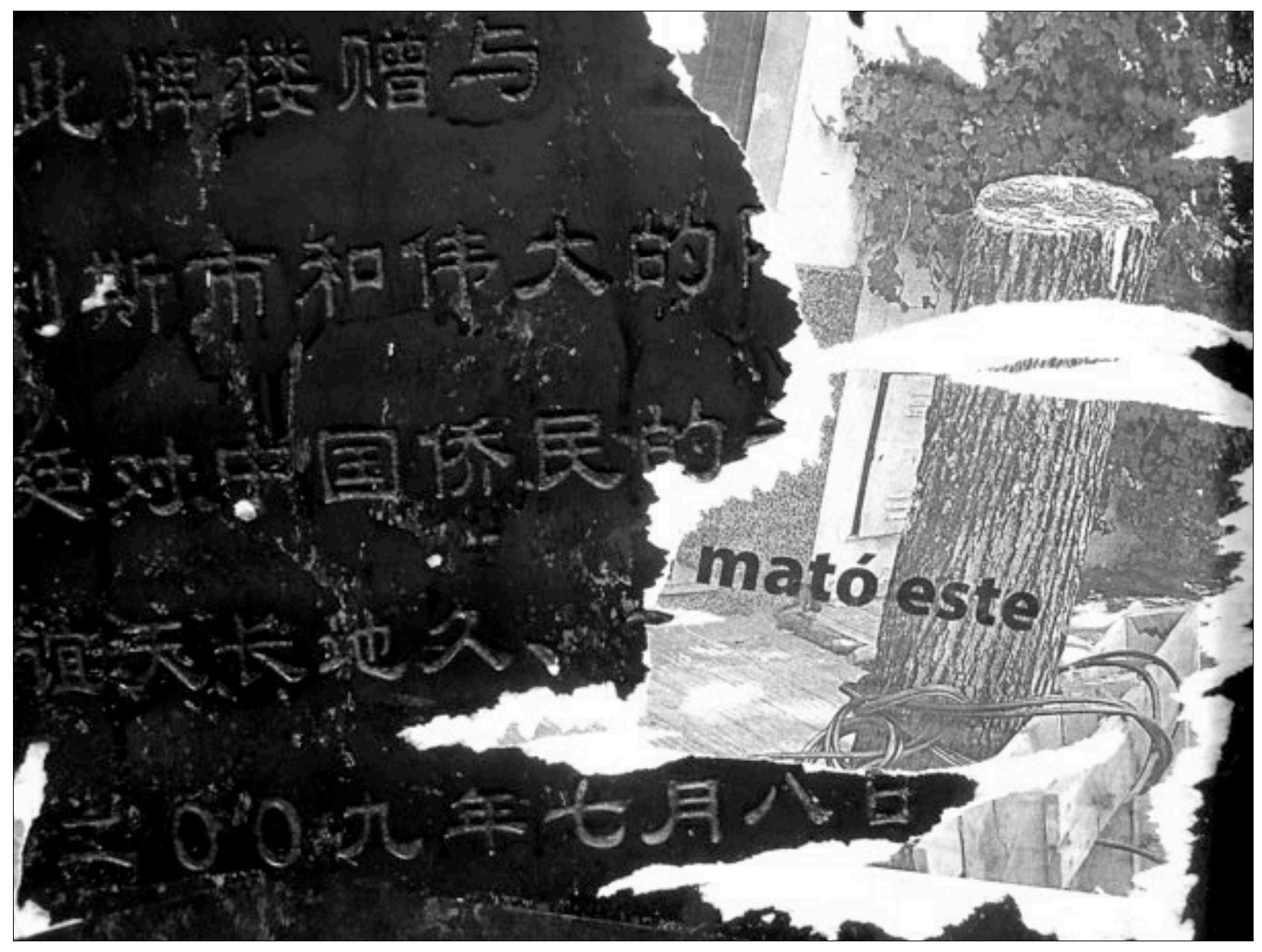

Figure 2 - The stele at the bottom of the pailou after being vandalized. 


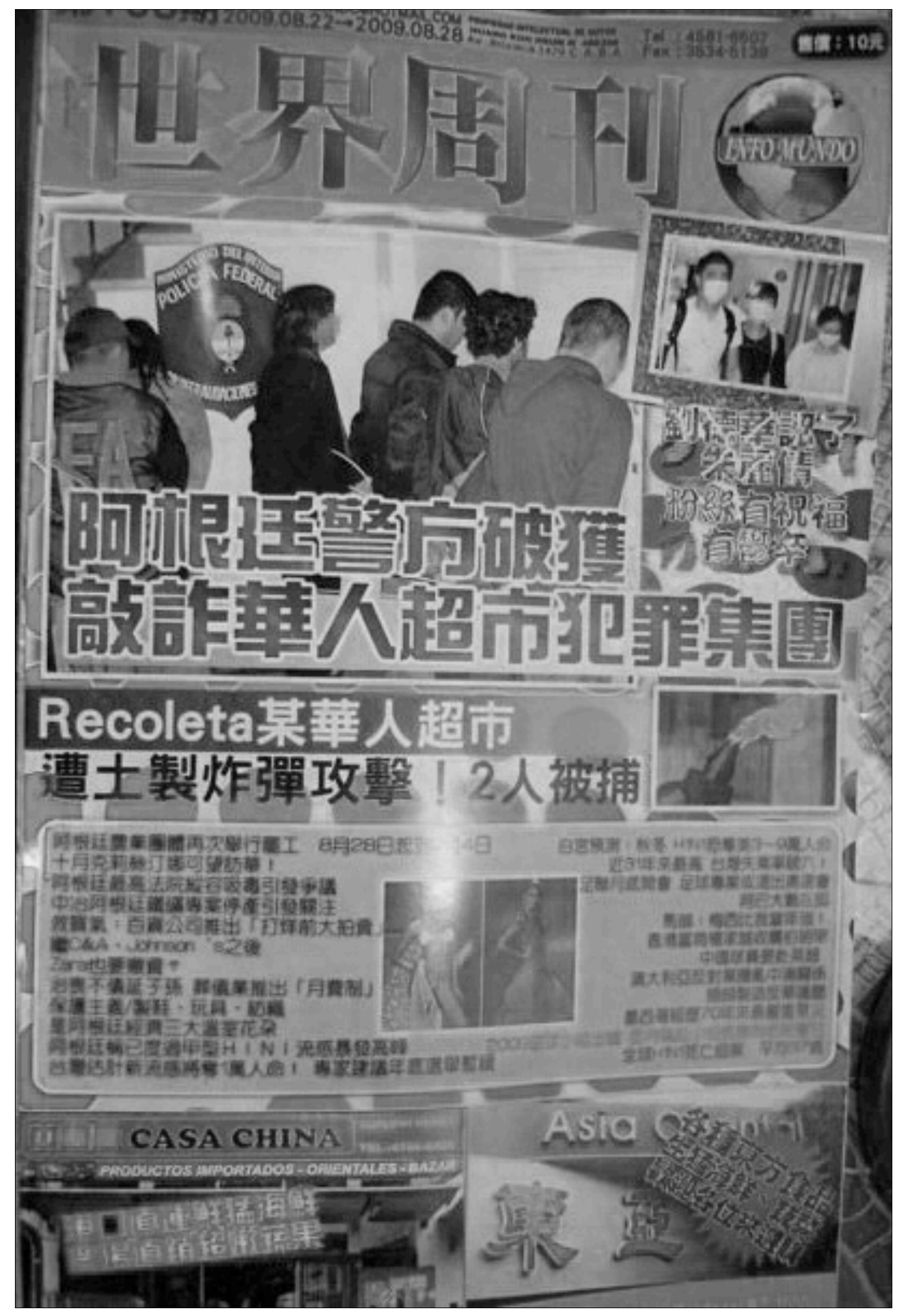


Figure 3 - Info Mundo, one of the three major Chinese-language news magazines in Argentina. All of the major headlines in this issue have to do with Chinese-run supermarkets.

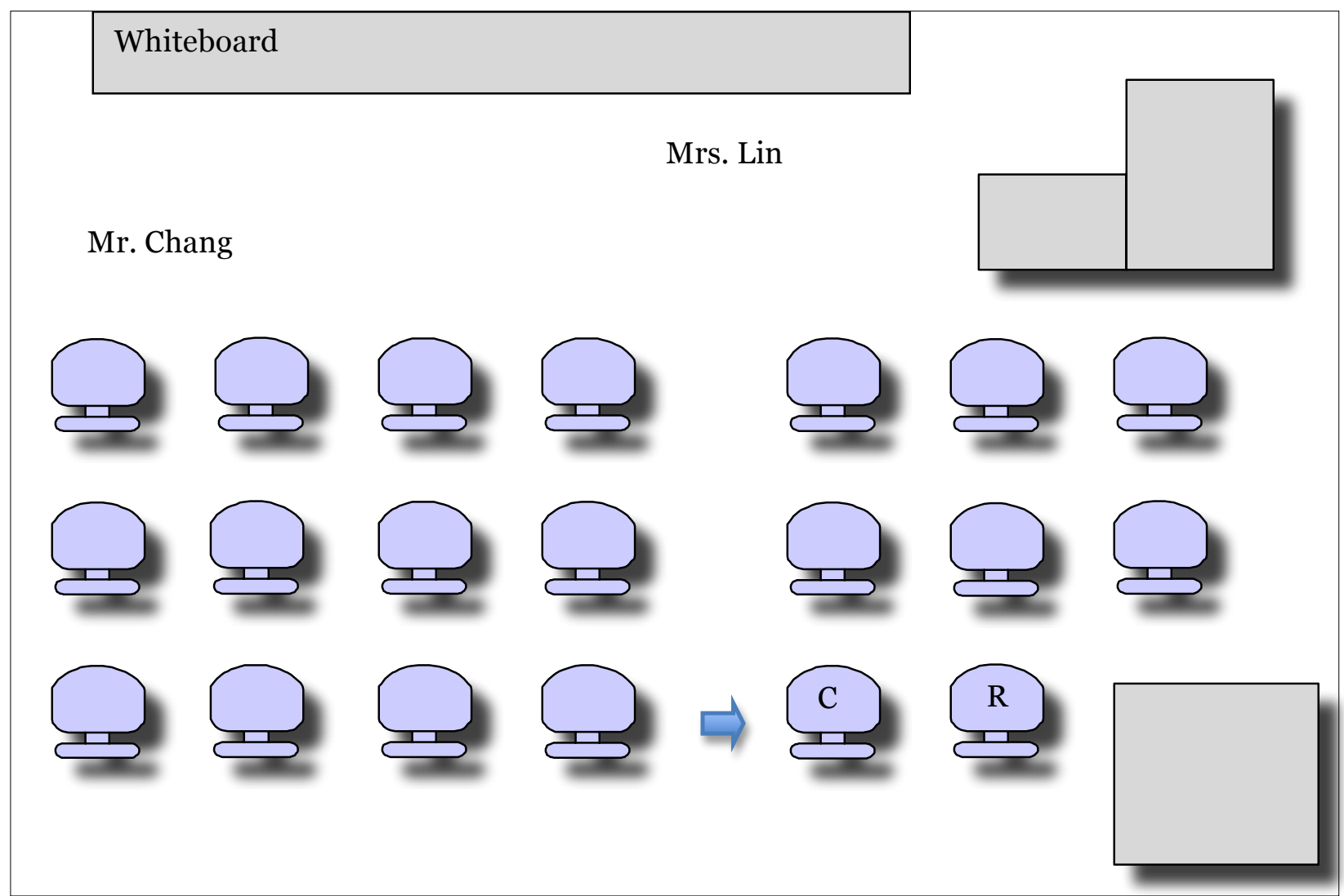

Figure 3 - Mrs. Lin's classroom. The arrow indicates the row where I sat with Rubén. I sat on the left, and he sat on the right. 


\section{Appendix 2 - Interview Rubric}

1. Basic information
a. Name
b. Gender
c. Age (approximate)
d. Place of birth
e. Number of years lived in Argentina
f. Marital status and children

2. Reason(s) for immigrating to Argentina

3. Place of residence and relationship with neighbors

4. First impressions of Argentina

5. Experiences with discrimination and racism

6. Work
a. Type of profession
b. Nationality/ethnicity of employer
c. Nationality/ethnicity of coworkers
d. Job satisfaction

7. Closest friends in Argentina - Argentine or Chinese/Taiwanese/other?

8. Sources of news about Argentina and home country

9. Groups and organizations

10. Argentine citizen? Why or why not?

11. Reverse culture shock upon return to home country?

12. Cultural practices maintained - Argentine, home culture

13. Interaction with native-born Argentines

14. Best and worst parts of living in Argentina

15. Plans for the future

16. Return to live in home country? 